ZAPISKi HistoryczNe t. 86, 2021, z. 3, s. 5-33

ISSN 0044-1791

http://dx.doi.org/10.15762/ZH.2021.21

JERZY DYGDAEA*

(iD https://orcid.org/0000-0002-9804-6845

DANUTA JANICKA**

(iD) https://orcid.org/0000-0002-2873-8088

\title{
O FENOMENIE DOROBKU NAUKOWEGO \\ Profesora Stanisława Salmonowicza
}

\author{
Abstract \\ On the Phenomenon \\ of Professor Stanisław Salmonowicz's Academic Output
}

The article presents a statistical description and analysis of the academic output of Professor Stanisław Salmonowicz, a historian and lawyer who has long been associated with Toruń. His output consists of c. 1350 publications, including over 60 books, almost 500 scholarly articles and c. 480 book reviews. The chronological framework of Salmonowicz's scholarly interests ranges from the sixteenth century to the present day and encompasses both the history of Europe (notably the history of France, Austria and Prussia) and history of Poland with particular emphasis on the history of Pomerania and the city of Torun. An important place in this output is occupied by the history of law and political systems of European countries. Salmonowicz's academic publications include monographs on, among other things, the Academic Gymnasium in Torun in the seventeenth to nineteenth centuries, the codification of penal law in the age of the Enlightened Absolutism, the Polish Underground State of 1939-1945, and the Warsaw Uprising of 1944; as well as numerous scholarly articles on the culture of old Torun, political and religious matters of the Polish-Lithuanian Commonwealth and the history of law. Moreover, Salmonowicz is the author of comprehensive books on King Frederick the Great of Prussia and the history of the Prussian state. He has also authored numerous chapters in books published in the series dedicated to the history of Torun and Pomerania. His works also include many texts that can inspire further academic inquiries. For example, his research into early modern witch trials and the morally questionable attitudes of certain Poles under Nazi and Soviet occupation during the Second World War may be an excellent point of departure for further historical investigations.

Keywords: Stanisław Salmonowicz; Polish historiography; history of historiography; history of law; early modern history; Pomerania; Prussia

\footnotetext{
* Instytut Historii, Polska Akademia Nauk

(@) jdygdala@ihpan.edu.pl

** Wydział Prawa i Administracji, Uniwersytet Mikołaja Kopernika w Toruniu

(ब) janicka@umk.pl
} 
W 2001 r. środowisko polskich historyków i historyków prawa uroczyście obchodziło 70 rocznicę urodzin prof. Stanisława Salmonowicza. Ukazała się wówczas obszerna księga pamiątkowa zatytułowana Historia integra. Tytuł tej publikacji bardzo dobrze oddawał wielostronność, tak pod względem chronologicznym, jak i rzeczowym, zainteresowań badawczych jubilata. Zwrócono na to uwagę w kilku krótkich szkicach autorstwa Ryszarda Łaszewskiego, Jerzego Dygdały, Danuty Janickiej i Grzegorza Górskiego². W księdze tej znalazła się także bibliografia prac opublikowanych przez Stanisława Salmonowicza, licząca aż 954 pozycje. Od 2001 r. Profesor wciąż wydaje kolejne książki i artykuły, pisze recenzje, jak również z upodobaniem zajmuje się publicystyką na łamach codziennych gazet, tygodników i miesięczników społeczno-kulturalnych. W przypadające w 2021 r. 90-lecie urodzin Profesora Redakcja „Zapisek Historycznych” postanowiła udokumentować ten bogaty i różnorodny dorobek naukowy z zakresu badań nad dziejami Pomorza, a także Polski i Europy, w dużym stopniu zamieszczany także na łamach „Zapisek”, oraz publicystyczny, publikując przygotowaną przez samego Stanisława Salmonowicza (przy współpracy Macieja J. Mazurkiewicza i Adama Biedrzyckiego) bibliografię jego prac z lat 2001-2021. Obejmuje ona 375 nowych publikacji.

Autorzy niniejszego szkicu zdecydowali się podjąć próbę podsumowania dotychczasowego dorobku naukowego prof. Stanisława Salmonowicza. Ponieważ pod względem zakresu chronologiczno-rzeczowego byłoby to zadanie niezwykle trudne i analiza taka wymagałaby współpracy co najmniej kilku jeszcze specjalistów, postanowiliśmy posłużyć się statystycznym ujęciem tego ogromu publikacji (uwzględniając główne zainteresowania badawcze jubilata) i wskazać na jego najważniejsze osiągnięcia naukowe w poszczególnych dziedzinach nauk historycznych i historyczno-prawnych. Można w tym miejscu zresztą wskazać, że sam Profesor w swych wspomnieniach zatytułowanych „Życie jak osioł ucieka...” podjął taką próbę liczbowego ujęcia swego dorobku naukowego ${ }^{3}$.

Trzeba w tym miejscu w skrócie przypomnieć drogę naukową Stanisława Salmonowicza. Jego ojciec, Antoni, pochodził ze starej rodziny średnioszlacheckiej osiadłej w Wielkim Księstwie Litewskim. Po odzyskaniu przez Polskę

${ }^{1}$ Historia integra. Ksiega pamiątkowa ofiarowana prof. Stanislawowi Salmonowiczowi w siedemdziesięciolecie urodzin, red. Jerzy Dygda£a [et al.], Toruń 2001.

${ }^{2}$ Ryszard Łaszewski, Profesor Stanisław Salmonowicz - biografia naukowa, [in:] Historia integra. Księga pamiatkowa ofiarowana prof. Stanislawowi Salmonowiczowi w siedemdziesięciolecie urodzin, red. Jerzy DygdaŁa [et al.], Toruń 2001, s. 11-14; Jerzy Dygda£a, Badania Stanistawa Salmonowicza nad historiq Torunia i Pomorza, [in:] ibid., s. 15-17; Danuta JANICKA, Wiek XVIII i XIX w twórczości naukowej Profesora Salmonowicza, [in:] ibid., s. 19-22; Grzegorz GóRski, Stanisław Salmonowicz jako badacz historii XX stulecia, [in:] ibid., s. 23-25.

${ }^{3}$ Stanisław Salmonowicz, „Życie jak osioł ucieka...”. Wspomnienia, Bydgoszcz-Gdańsk 2014, s. 360, 409-410. 
niepodległości w 1918 r. pełnił funkcje urzędnicze w ówczesnej administracji państwowej na ziemiach północno-wschodnich (był m.in. wicestarostą w Nowogródku oraz starostą w Kamieniu Koszyrskim na Polesiu). Matka, Stefania z Muzyczków związana była z Krakowem. Profesor urodził się 9 XI 1931 r. wprawdzie w Brześciu nad Bugiem, ale nie był dłużej związany z tym miastem. Po przedwczesnej śmierci ojca w 1935 r. matka z dwoma synami, starszym Jerzym (1925-2011), późniejszym adiunktem Politechniki Gdańskiej i Instytutu Oceanografii Polskiej Akademii Nauk, i młodszym Stanisławem, mieszkała w Wilnie i to z tym miastem wiążą się wspomnienia Profesora z dzieciństwa. W czasie drugiej wojny światowej rodzina przeniosła się do Warszawy, gdzie przebywała w latach 1943-1944, po czym, już po wybuchu powstania warszawskiego, udało się jej przedostać do Krakowa, gdzie znalazła schronienie w domu dziadków Profesora. Po wojnie, po krótkim epizodzie zielonogórskim, Stanisław Salmonowicz znów osiadł w Krakowie, gdzie w 1950 r. zdał maturę i rozpoczął studia prawnicze na Uniwersytecie Jagiellońskim. Jego mistrzem był wybitny historyk prawa, prof. Michał Patkaniowski. Pod jego kierunkiem napisał pracę magisterską poświęconą działalności sądów francuskich podczas radykalizacji rewolucji w latach 1792-1794. Już wcześniej, bo w 1953 r. opublikował swój pierwszy tekst w „Tygodniku Powszechnym”, gdzie ukazało się omówienie świeżo wydanej książki znanego belgijskiego (piszącego po francusku) polonisty i slawisty Claude’a Backvisa o Stanisławie Wyspiańskim ${ }^{4}$. Po ukończeniu studiów w 1954 r. S. Salmonowicz zaczął pracę jako asesor, a następnie sędzia cywilny w ówczesnym wymiarze sprawiedliwości na terenie Małopolski ${ }^{5}$.

W 1956 r. S. Salmonowicz dostał się na studia aspiranckie (doktoranckie) na seminarium znakomitego historyka prawa, prof. Karola Koranyiego na Uniwersytecie Warszawskim. Już trzy lata później uzyskał tam stopień doktora na podstawie opublikowanej następnie drukiem rozprawy Krystian Bogumił Steiner (1746-1814), toruński prawnik i historyk $k^{6}$. Pozwoliło mu to w 1959 r. otrzymać etat adiunkta w macierzystej Katedrze Powszechnej Historii Państwa i Prawa Uniwersytetu Jagiellońskiego u prof. Michała Patkaniowskiego. Zainteresowania badawcze S. Salmonowicza koncentrowały się wówczas na problematyce rewolucji francuskiej i na osiemnastowiecznych wielkich

${ }^{4}$ Idem, Backwis o Wyspiańskim, Tygodnik Powszechny, 1953, nr 29, s. 5. Omówienie dotyczyło książki: Claude BACKvis, Le dramaturge Stanislas Wyspiański (1869-1907), Paris 1952.

${ }^{5}$ Podstawowe informacje dotyczące życiorysu Profesora zaczerpnięto z jego autobiografii pt. „Życie jak osioł ucieka...”; por. też jego własne opracowanie: Stanisław SALMONowicz, Jak studiowałem $w$ dobie polskiego stalinizmu, Analecta. Studia i Materiały z Dziejów Nauki, t. 11: 2002, z. 1-2, s. 313-336; zob. też R. ŁAszEwsKI, op.cit., s. 11-14.

${ }^{6}$ Stanisław Salmonowicz, Krystian Bogumit Steiner (1746-1814), toruński prawnik i historyk. Studium z dziejów nauki prawa doby Oświecenia w Polsce, Toruń 1962. 
kodyfikacjach prawa. $Z$ tą też tematyką wiązała się jego rozprawa habilitacyjna Prawo karne oświeconego absolutyzmu. Z dziejów kodyfikacji karnych przełomu XVIII/XIX $w^{7}{ }^{7} \mathrm{~W}$ tym też okresie czynnie uczestniczył w krakowskim życiu naukowym, społeczno-politycznym (co wzbudziło podejrzenia Służby Bezpieczeństwa) i artystycznym, m.in. był krótko związany ze słynną Piwnicą pod Baranami ${ }^{8}$. Po habilitacji, nie widząc przed sobą perspektyw szybkiego awansu naukowego w Krakowie, zdecydował się przenieść do Torunia. Zachęcił go do tego jego przyjaciel Zbigniew Zdrójkowski, poznany na seminarium prof. Koranyiego, ówczesny docent na Wydziale Prawa Uniwersytetu Mikołaja Kopernika w Toruniu.

Od 1 IX 1966 r. Stanisław Salmonowicz zaczął pełnić funkcję kierownika Katedry Historii Państwa i Prawa na Wydziale Prawa toruńskiego uniwersytetu. Wiązało się to jednak z wyraźną zmianą jego priorytetów badawczych. Już wcześniej Z. Zdrójkowski zachęcał go do głębszych studiów nad historią toruńskiego Gimnazjum Akademickiego w dobie baroku i oświecenia. Miało to być niejako nawiązanie do rozprawy doktorskiej poświęconej toruńskiemu uczonemu Krystianowi Bogumiłowi Steinerowi. Profesor Salmonowicz z prawdziwą pasją rozpoczął pogłębione studia nad tą tematyką. Ostatecznie obszerna, licząca 450 stron, monografia toruńskiego Gimnazjum Akademickiego, oparta na niewykorzystanych dotąd obfitych materiałach źródłowych, ukazała się drukiem w 1973 r., uświetniając jubileusz 400-lecia tej zasłużonej szkoły ${ }^{9}$. Do dziś jest to jedna z najlepszych prac z historii oświaty i nauki dawnej Rzeczypospolitej.

W tym czasie, w końcu września 1970 r., Profesor został zatrzymany przez aparat bezpieczeństwa PRL, m.in. w związku z kontaktami z ośrodkami polskiej emigracji (w tym z „Wolną Europą” i paryską „Kulturą”). Zresztą krakowska Służba Bezpieczeństwa już od dawna obserwowała jego działalność, podejrzewając go o inspirowanie „opozycji rewizjonistycznej”. Tak zwane wydarzenia grudniowe 1970 r. i zmiana ekipy politycznej, która przejściowo ograniczyła represje, sprawiły, że 21 I 1971 r. został wypuszczony z aresztu ${ }^{10}$. Mimo to ówczesne Ministerstwo Oświaty i Szkolnictwa Wyższego 1 III 1971 r. zwolniło go z pracy na UMK. Po dłuższych zabiegach życzliwych mu osób spośród

${ }^{7}$ Idem, Prawo karne oświeconego absolutyzmu. Z dziejów kodyfikacji karnych przełomu XVIII/XIX w., Toruń-Poznań 1966.

${ }^{8}$ Idem, Krakowskie "prehistoryjki opozycyjne” lat 1956-1966, Arcana, nr 68: 2006, z. 2, s. 70-99; idem, „Piwnica pod Baranami”, czyli w poszukiwaniu utraconego czasu, Przegląd Artystyczno-Literacki, 1995, nr 1-2, s. 30-31.

${ }^{9}$ Idem, Ksiega pamiątkowa 400-lecia Toruńskiego Gimnazjum Akademickiego, t. 4: Toruńskie Gimnazjum Akademickie w latach 1681-1817. Studium z dziejów nauki i oświaty, red. Zbigniew ZDRójKowski, Poznań 1973.

${ }^{10}$ Zob. szerzej: idem, Moja sprawa karna 1970/1971, Dzieje Najnowsze, R. 42: 2010, z. 4, s. $115-139$. 
wybitnych uczonych, zdających sobie sprawę z jego dotychczasowych dokonań naukowych, został on 1 II 1972 r. zatrudniony w Zakładzie Historii Pomorza Instytutu Historii Polskiej Akademii Nauk. W tej sytuacji jest rzeczą oczywistą, że badania Profesora coraz bardziej koncentrowały się na historii ustroju, oświaty i szeroko pojętych dziejów kultury Pomorza Nadwiślańskiego (ale też Prus Wschodnich), ze szczególnym uwzględnieniem przeszłości nowożytnego Torunia. Szczególne znaczenie miało współautorstwo kolejnych tomów Historii Torunia i monumentalnej Historii Pomorza. W przypadku tej drugiej serii został redaktorem czwartego tomu, obejmującego dzieje Wielkiego Pomorza w XIX i początkach XX w. W latach 1993-2002 pełnił funkcję kierownika Zakładu Historii Pomorza IH PAN. W związku z tzw. karnawałem „Solidarności” z lat 1980-1981 władze UMK zabiegały o ponowne zatrudnienie Profesora na uczelni i o unieważnienie wcześniejszej decyzji ministerstwa o zwolnieniu go z pracy. Ostatecznie przyniosło to pożądany efekt i od 1 II 1982 r. S. Salmonowicz znowu został zatrudniony na Wydziale Prawa - formalnie w wymiarze pół etatu. Objął też wówczas kierownictwo Zakładu (Katedry) Historii Prawa Niemieckiego w Polsce. Za swój pierwszy zakład pracy uważał jednak Instytut Historii PAN.

W latach osiemdziesiątych i dziewięćdziesiątych XX w. Profesor prowadził niezwykle owocne badania na wielu polach badawczych. Jego liczne prace dotyczyły nie tylko dziejów Torunia i szeroko rozumianego Pomorza, lecz także historii państwa pruskiego, Francji w XVIII-XIX w., oświeconego absolutyzmu, a także kultury, oświaty, nauki oraz specyfiki wyznaniowej nowożytnej Rzeczypospolitej. Kontynuował też badania nad historią dawnego prawa, ustroju i administracji. W 1983 r. uzyskał tytuł profesora nadzwyczajnego, a w 1989 r. profesora zwyczajnego. Zasadnicza zmiana ustrojowa w 1989 r. i likwidacja cenzury pozwoliły mu na swobodne podejmowanie tematyki dziejów najnowszych, zwłaszcza czasów drugiej wojny światowej i epoki stalinizmu w Polsce. Aktywnie uczestniczył w życiu naukowym, wygłaszając referaty na licznych konferencjach w Polsce i za granicą. Prowadził też nadal zajęcia dydaktyczne na Wydziale Prawa UMK, i to aż do 2016 r. (mimo że formalnie w 2001 r. przeszedł na emeryturę). W czasach PRL działacz demokratycznej opozycji (podobnie jak jego brat Jerzy), po roku 1989 czynnie wspierał swym autorytetem tworzące się wówczas ugrupowania polityczne: Ruch Obywatelski Akcja Demokratyczna i następnie Unię Wolności.

Profesor Stanisław Salmonowicz wciąż jest bardzo aktywny naukowo (nie stroni przy tym od publicystyki), o czym najlepiej świadczy zamieszczona w tym zeszycie „Zapisek Historycznych” bibliografia jego publikacji za lata 2001-2021. Łączna liczba wydanych przez niego w latach 1953/1956-2020 książek, artykułów naukowych, biogramów, recenzji, felietonów i wspomnień sięga ok. 1340 pozycji. Oznacza to, że przeciętnie każdego roku publikuje 
21 prac. $\mathrm{Z}$ tego niezwykle bogatego dorobku na szeroko pojętą publicystykę przypada przeszło 240 tekstów (18,3\%). Są to przeważnie felietony, krótkie artykuły popularnonaukowe i wywiady. Ukazywały się one naprzód w „Tygodniku Powszechnym” i „Więzi” (częściowo pod pseudonimem), później też w toruńskiej prasie codziennej („Nowościach”, „Gazecie Pomorskiej”), w tygodnikach i miesięcznikach (były to m.in. warszawska „Polityka”, „Forum Akademickie” i „Nowe Książki” oraz regionalne „Kujawy”, „Promocje KujawskoPomorskie”, wydawany przez UMK „Głos Uczelni”, a także gdańskie „Litery”). W latach 2013-2019 jego felietony na tematy historyczne, obyczajowe i dotyczące współczesnych wydarzeń kulturalno-politycznych były publikowane na łamach ukazującego się w Gdańsku miesięcznika „Pomerania”. W 2019 r. zostały one wydane w formie książkowej pt. Gawędy o ludziach i książkach ${ }^{11}$. Tę publicystyczną twórczość kontynuuje zresztą Profesor do dziś. Wystarczy wskazać na ciepłe wspomnienie o zmarłej niedawno znakomitej badaczce epoki nowożytnej, a także dziejów Gdańska i Pomorza, prof. Marii Boguckiej ${ }^{12}$ i na wywiad udzielony „Gazecie Pomorskiej” przy okazji rocznicy wyborów czerwcowych z 1989 r., w którym obok wątków dotyczących przemian politycznoustrojowych znajdujemy też wzmiankę o "spotkaniach" młodziutkiego wtedy jubilata z samym marszałkiem Józefem Piłsudskim (w Wilnie) i z prezydentem Ignacym Mościckim (w Wyrzysku) ${ }^{13}$.

Blisko 1100 prac S. Salmonowicza to publikacje scricte naukowe $(81,7 \%$ całości dorobku). Niektóre z tych pozycji cieszą się zresztą dużą popularnością. Wystarczy wskazać na Pitaval krakowski (współautorami byli Janusz Szwaja i Stanisław Waltoś) - mający sześć wydań, Fryderyka Wielkiego - cztery wydania czy na syntezę Prusy. Dzieje państwa i społeczeństwa - trzy wydania polskie oraz tłumaczenie niemieckie. Także niektóre artykuły (zwłaszcza z historii prawa) ukazały się w wersjach obcojęzycznych, głównie francuskiej i niemieckiej.

Cechą charakterystyczną twórczości Profesora jest wyraźna skłonność do pisania recenzji, nie tak częsta u współczesnych historyków. Doliczyliśmy się aż 530 recenzji, co stanowi $48 \%$ wszystkich jego publikacji naukowych. Nie są to bynajmniej opinie grzecznościowe, są one bardzo merytoryczne i nieraz wprawiają w zakłopotanie autorów recenzowanych prac. Profesor Salmonowicz jest zresztą autorem swego rodzaju poradnika, książki O rzemiośle

${ }^{11}$ Idem, Gawędy o ludziach i książkach. Felietony publikowane w miesięczniku „Pomerania” w latach 2013-2019, opr. Maciej J. Mazurkiewicz, Gdańsk 2019.

${ }^{12}$ Idem, Maria Bogucka (1929-2020), Pomerania. Miesięcznik Społeczno-Kulturalny, 2021, nr 2 (550), s. 53-54.

${ }^{13}$ Po wyborach 4 czerwca 1989 roku szybko weszliśmy do pelnych marketów, ale z pustym portfelem, ze Stanisławem Salmonowiczem rozmawia Adam Willma, Gazeta Pomorska, 4 VI 2021, s. 18-19. 
recenzent $a^{14}$. Tak duża liczba recenzji wynika w jakiejś mierze z tego, że S. Salmonowicz przez długi czas był stałym recenzentem znanego francuskiego czasopisma „Revue historique de droit français et étranger”, na którego łamach omawiał ukazujące się w Niemczech (ale też we Francji, w Anglii i w Polsce) prace $\mathrm{z}$ historii prawa, ustroju i administracji.

W twórczości naukowej Stanisława Salmonowicza można wyodrębnić co najmniej kilka podstawowych działów. Zaliczyć do nich można historię wczesnonowożytną, tak Rzeczypospolitej, jak i powszechną (XVI-XVIII w.), historię XIX w. (do 1914 r.), dzieje Prus (i szerzej Niemiec), historię najnowszą, dzieje szeroko rozumianego Pomorza (zwłaszcza Torunia) od XVI do XX w. włącznie, historię kultury, oświaty i nauki, wreszcie zajmującą szczególnie ważne miejsce historię prawa i ustroju. Podjęliśmy wprawdzie próbę statystycznego ujęcia tego podziału, jest on jednak nieprecyzyjny, gdyż trzeba pamiętać, że spora część publikacji Profesora może być zaliczona jednocześnie do kilku dyscyplin naukowych. Przykładowo obszerna monografia źródłowa Toruńskie Gimnazjum Akademickie w latach 1681-1817 (opublikowana jako czwarty tom Ksieggi pamiatkowej 400-lecia Toruńskiego Gimnazjum Akademickiego) jest jednocześnie pracą z historii Torunia, dziejów oświaty i nauki, a w jakiejś mierze także $\mathrm{z}$ historii nowożytnej i historii XIX $\mathrm{w}$.

W dotychczasowym dorobku Profesora wyraźnie dominują liczbowo prace z zakresu historii prawa, ustroju i administracji. Jest ich ok. 330, co stanowi prawie $30 \%$ wszystkich publikacji naukowych. Wśród nich książki (18 pozycji) i artykuły (w czasopismach i pracach zbiorowych -90 pozycji) stanowią $33 \%$, a 219 recenzji to pozostałe $67 \%$. Na drugim miejscu znajdują się prace $\mathrm{z}$ historii wczesnonowożytnej, tak z historii powszechnej (zwłaszcza Niemiec i Francji), jak i z dziejów polsko-litewskich XVI-XVIII w. Zaliczyliśmy do nich ok. 200 pozycji (18\% całości dorobku naukowego), w tym książki (14) i artykuły (69) obejmują 41\%, a 118 recenzji stanowi 59\%. Publikacje dotyczące XX w. (zwłaszcza okresu drugiej wojny światowej oraz czasów stalinowskich w PRL) zajmują trzecie miejsce (prawie 150 prac, to jest 13,5\%). Jest wśród nich 11 publikacji książkowych i 80 artykułów (razem 61\%) oraz 57 recenzji (39\%). Pewne trudności mogą być z zaliczeniem poszczególnych prac Profesora do działu umownie przez nas nazwanego „Toruń i Pomorze Nadwiślańskie (Prusy Królewskie i Zachodnie)”. Tej tematyki dotyczy przeszło 130 pozycji (12\%), faktycznie jednak niektóre prace z innych działów (choćby $\mathrm{z}$ historii najnowszej) także są powiązane z problematyką pomorską. Dominują tu książki (10) i artykuły (105) stanowiące $86,5 \%$, podczas gdy recenzje są stosunkowo nieliczne (jedynie 18, tj. 13,5\%). Co najmniej 104 prace z szeroko

${ }^{14}$ Stanisław Salmonowicz, O rzemiośle recenzenta. Studia $z$ warsztatu historyka, Warszawa 1999. 
pojętych dziejów kultury, oświaty i nauki stanowią 9,5\% dorobku naukowego S. Salmonowicza. Znów przeważają wśród nich książki (5) i artykuły (70) - razem 72\%; recenzji jest już mniej, bo tylko 29 (28\%). Niejako na dalszym planie stoją studia nad historią XIX w., niemniej jednak i w tej dziedzinie dorobek Profesora jest pokaźny, obejmując trzy książki i 18 artykułów (36\% publikacji $\mathrm{z}$ tego działu) oraz 38 recenzji (64\%), razem stanowi to jednak tylko 5\% jego twórczości naukowej. Zamykają tę statystykę biogramy (głównie osób czynnych w XVIII w.) w Polskim słowniku biograficznym, Słowniku biograficznym Pomorza Nadwiślańskiego oraz w Toruńskim słowniku biograficznym (łącznie 63 pozycje), a także 14 nekrologów zamieszczonych w różnych czasopismach; łącznie jest to 77 tekstów (7\% całości dorobku naukowego).

Warto spojrzeć na twórczość naukową Profesora także w ujęciu czasowym. Początkowo w latach 1956-1970 ogłaszał on drukiem przeciętnie od 6 do 10 publikacji rocznie, potem w latach $1971-1985$ było to po 15-20 prac rocznie, a w latach 1986-2000 wystąpiło „apogeum” tej twórczości, sięgając rocznie 31 publikacji. Później tempo nieco spadło, wahając się od 9 do 17 pozycji rocznie. Działalność publicystyczna S. Salmonowicza rozwinęła się w pełni dopiero po $1989 \mathrm{r}$. Wcześniej były to pojedyncze pozycje (jedna lub dwie rocznie), podczas gdy w latach 1991-1995 Profesor opublikował aż 68 felietonów i innych wypowiedzi publicystycznych, a w latach 2011-2020 (a nawet 2021) przeszło 40 tekstów tego typu.

Można również przyjrzeć się preferencjom naukowym Profesora, biorąc pod uwagę pięcioletnie przedziały czasowe, poczynając od $1965 \mathrm{r}$. Wcześniej, w latach 1956-1965 dominowały prace z zakresu historii prawa (26) i historii nowożytnej (14). W pięcioleciu 1966-1970 obie dyscypliny zachowywały względną równowagę (odpowiednio 16 i 17 prac). Później w latach 1971-1975 przewagę uzyskała historia nowożytna (25 do 19). Na trzecim miejscu znalazła się jednak problematyka dziejów kultury i oświaty (18 prac), a po niej, praktycznie nieobecna wcześniej, tematyka toruńsko-pomorska (12 prac), co wyraźnie wiązało się z przejściem Profesora z Uniwersytetu Jagiellońskiego na UMK w Toruniu. W latach 1976-1980 znów dominowała historia prawa (23 prace) - przed tematyką toruńską (16 pozycji) i historią nowożytną (11 publikacji). W okresie 1981-1985 na czoło wysunęły się prace dotyczące historii Torunia i Prus Królewskich (35), niemal dorównywały im liczbowo publikacje z historii prawa (34), a na trzecim miejscu ulokowała się historia nowożytna (25). Lata 1986-1990 to z kolei przewaga publikacji z zakresu historii nowożytnej (43 pozycje) nad dziejami prawa i ustroju (35), podczas gdy prac o tematyce toruńsko-pomorskiej było jedynie 17. Między rokiem 1991 a 1995 pojawiła się (po zniesieniu cenzury) większa liczba prac poświęconych wydarzeniom z XX w. (20), ale nadal dominowały publikacje z zakresu historii prawa (aż 51) i z historii nowożytnej (27). Zmiana nastąpiła w następ- 
nym okresie, tj. w latach 1996-2000. Profesor opublikował wówczas 49 pozycji z historii prawa i 24 z dziejów XX w., podczas gdy historii nowożytnej dotyczyło tylko 13 prac. Dzieje prawa dominowały nadal w latach 2001-2005 i 2006-2010 (28 i 29 pozycji) wobec 22 i 16 prac z zakresu XX w. oraz 13 i 14 publikacji z historii nowożytnej. Po 2011 r. prace z dziejów najnowszych (29) przeważają już nad historią prawa (17) oraz historią nowożytną i problematyką pomorską (po 9 pozycji).

Nieco inaczej będzie wyglądała ta statystyka, jeżeli z naszych analiz wyłączymy recenzje i weźmiemy pod uwagę wyłącznie książki i artykuły naukowe.

Tab. 1. Publikacje Stanisława Salmonowicza z lat 1956-2020 w ujęciu liczbowym i rzeczowym

\begin{tabular}{|l|r|r|r|r|r|r|r|}
\hline $\begin{array}{r}\text { Tema- } \\
\text { tyka }\end{array}$ & $\begin{array}{c}\text { Historia } \\
\text { prawa }\end{array}$ & $\begin{array}{c}\text { Historia } \\
\text { nowo- } \\
\text { żytna }\end{array}$ & $\begin{array}{c}\text { Historia } \\
\text { XIX w. }\end{array}$ & $\begin{array}{c}\text { Historia } \\
\text { najnow- } \\
\text { sza }\end{array}$ & $\begin{array}{c}\text { Toruń } \\
\text { i Pomo- } \\
\text { rze }\end{array}$ & $\begin{array}{c}\text { Kultura } \\
\text { i oświata }\end{array}$ & $\begin{array}{c}\text { Biogra- } \\
\text { my i ne- } \\
\text { krologi }\end{array}$ \\
\hline $1956-1960$ & 5 & 4 & 1 & 1 & - & 1 & - \\
\hline $1961-1965$ & 10 & 2 & - & - & - & 2 & 1 \\
\hline $1966-1970$ & 8 & 5 & - & - & 2 & 4 & 1 \\
\hline $1971-1975$ & 4 & 4 & - & - & 10 & 12 & 2 \\
\hline $1976-1980$ & 5 & 5 & - & 1 & 14 & 9 & 5 \\
\hline $1981-1985$ & 6 & 14 & 4 & 4 & 32 & 3 & 3 \\
\hline $1986-1990$ & 6 & 19 & 4 & 8 & 14 & 8 & - \\
\hline $1991-1995$ & 16 & 16 & 4 & 12 & 10 & 10 & 25 \\
\hline $1996-2000$ & 13 & 7 & 3 & 16 & 12 & 10 & 28 \\
\hline $2001-2005$ & 6 & 4 & 4 & 17 & 9 & 2 & 5 \\
\hline $2006-2010$ & 14 & 6 & - & 10 & 4 & 10 & 4 \\
\hline $2011-2015$ & 8 & 5 & 1 & 13 & 5 & 1 & 1 \\
\hline $2016-2020$ & 7 & 2 & - & 10 & 2 & 3 & 2 \\
\hline
\end{tabular}

Z powyższego zestawienia wynika, że zainteresowania naukowe S. Salmonowicza historią prawa, ustroju i administracji przez cały czas utrzymywały się na mniej więcej stałym poziomie od początku jego kariery naukowej. Liczba publikacji z tej dziedziny dość wyraźnie jednak wzrosła w latach 1991-2010. Także badania nad historią nowożytną były kontynuowane z mniej więcej jednakowym natężeniem, przy czym wyraźna ich intensyfikacja nastąpiła w latach 1981-1995. Na tym tle dzieje XIX w. stanowią raczej margines wśród prac Profesora, ale zajmował się on także i tym okresem. Znacznie większe zainteresowanie przejawiał S. Salmonowicz historią najnowszą. Kiedyś zresztą stwierdził, że gdyby nie ograniczenia cenzuralne od samego początku swej działalności naukowej poświęcałby tej tematyce znacznie więcej uwagi. Dopiero 
po zniesieniu cenzury (choć zdarzało mu się wcześniej publikować poza jej zasięgiem) problematyka związana $\mathrm{z}$ Polskim Państwem Podziemnym i funkcjonowaniem systemu stalinowskiego znalazła odpowiednie miejsce $\mathrm{w}$ jego twórczości i po $1996 \mathrm{r}$. wysunęła się pod względem liczbowym na pierwsze miejsce. Sprawy toruńsko-pomorskie pojawiły się wśród publikacji Profesora stosunkowo późno, po 1966 r., co wiązało się z przeniesieniem się z Krakowa do Torunia, a następnie zatrudnieniem w Zakładzie Historii Pomorza IH PAN. W latach 1971-1985 prace z tego zakresu dość wyraźnie dominują w ówczesnej twórczości Profesora. Kwestie szeroko pojętych dziejów kultury, oświaty i nauki (głównie w epoce nowożytnej) stały się przedmiotem zainteresowań S. Salmonowicza od samego początku jego działalności naukowej. Do $2010 \mathrm{r}$. przeciętna ich liczba była mniej więcej stała, wahając się koło dwóch pozycji rocznie. Pamiętać jednak trzeba, że część z nich dotyczyła oświaty i nauki doby oświecenia w wielkich miastach Prus Królewskich, może więc też być zaliczona do tematyki pomorskiej. Wyraźnie ponadprzeciętna liczba publikacji z zakresu toruńsko-pomorskiego w latach 1981-1985 (32) oraz z działu biogramów w okresie 1991-2000 (53) wynika z faktu, że ukazały się wtedy trzy prace zbiorowe Zasłużeni ludzie Pomorza Nadwiślańskiego XVII wieku ${ }^{15}$ oraz Wybitni Pomorzanie XVIII wieku ${ }^{16}$, a także Wybitni ludzie dawnego Torunia ${ }^{17}$, w których Profesor zamieścił sporo artykułów biograficznych, a później wydano pierwsze tomy Toruńskiego stownika biograficznego ${ }^{18}$, gdzie S. Salmonowicz praktycznie zmonopolizował życiorysy toruńskich uczonych - profesorów gimnazjalnych, bibliofilów, a także pastorów i wydawców (drukarzy) doby nowożytnej.

Przechodząc do merytorycznej analizy niektórych aspektów twórczości S. Salmonowicza, chcielibyśmy przede wszystkim zwrócić uwagę na jej niezwykłą różnorodność pod względem tematycznym i zasięg chronologiczny sięgający od XVI w. aż do współczesności. W dobie wąskich specjalizacji charakteryzujących znakomitą większość obecnych naukowców jest to zjawisko bardzo rzadkie.

Z historią nowożytną i to powszechną miał Profesor pierwszy kontakt już podczas pisania pracy magisterskiej na Wydziale Prawa UJ. To zapewne stamtąd wyniósł zainteresowanie problematyką rewolucji francuskiej i jej radykalnych nurtów. Pisał, często krytycznie, o ówczesnych rewolucjonistach i ideologach, o mechanizmach przemocy i o terrorze, o próbach tworzenia nowego

${ }^{15}$ Zasłużeni ludzie Pomorza Nadwiślańskiego XVII wieku. Szkice biograficzne, Wrocław 1982.

${ }^{16}$ Wybitni Pomorzanie XVIII wieku. Szkice biograficzne, red. Józef Borzyszkowski [et al.], Gdańsk-Wrocław 1983.

${ }^{17}$ Wybitni ludzie dawnego Torunia, red. Marian Biskup, Warszawa 1982.

${ }^{18}$ Toruński słownik biograficzny, red. Krzysztof Mikulski, Toruń 1998-2000. 
porządku społecznego. Podsumowaniem pewnego etapu tych badań był zbiór szkiców Francja pod jakobińska gwiazdą ${ }^{19}$. Jednak także później ukazywały się artykuły związane z tą tematyką. Szczególnie ważna była publikacja analizująca przyczyny i przebieg chłopskiego powstania w Wandei wymierzonego $\mathrm{w}$ rewolucję pozornie głoszącą hasła wyzwolenia ludu z feudalnego ucisku ${ }^{20}$. Korzystając m.in. z materiałów dostarczonych przez Profesora i z jego przemyśleń, Paweł Jasienica napisał książkę o charakterze bardziej ogólnego eseju Rozważania o wojnie domowej ${ }^{21}$. Później ukazały się kolejne szkice Profesora dotyczące terroru jakobińskiego: Sylwetki spod gilotyny ${ }^{22}$. O trwałości zainteresowań tą problematyką może świadczyć opatrzenie przez S. Salmonowicza, stosunkowo niedawno, wstępem zatytułowanym Emanuel Joseph Sieyès i jego epoka, polskiego tłumaczenia głównego dzieła tegoż ideologa początkowego etapu rewolucji francuskiej ${ }^{23}$. Jest rzeczą charakterystyczną, że już w tym początkowym okresie swoich badań Profesor wyraźnie odciął się od marksistowskiego ujmowania tzw. procesu historycznego. W jakiejś mierze wiązało się to ze zmianami w polskiej nauce historycznej po przełomie $1956 \mathrm{r}^{24}$ Inna rzecz, że nigdy nie podzielał poglądów znacznej części historiografii francuskiej z jej uwielbieniem rewolucji i jakobińskiej „demokracji”. Można też dodać, że wysoko oceniał francuską szkołę Annales, koncentrującą się na historii społecznej ${ }^{25}$, i przyznawał się, że dostarczyła mu ona „pewnych impulsów badawczych" 26 , choć znalazło to raczej umiarkowane odbicie w jego twórczości naukowej opartej w znacznej mierze na klasycznej metodologii historii.

Nie ulega wątpliwości, że Profesor analizował sprawy francuskie okresu rewolucji na szerokim tle europejskiego oświecenia. Ważne miejsce zajmuje tu artykuł Wokół sporów o definicję i chronologię zjawiska Oświecenia ${ }^{27}$. Jednocześnie zajmował się także problematyką oświeconego absolutyzmu, w pełni doceniając jego znaczenie modernizacyjno-reformatorskie (ze szczególnym uwzględnieniem austriackiego józefinizmu). Wystarczy tu wskazać na artykuły

${ }^{19}$ Stanisław Salmonowicz, Francja pod jakobińską gwiazdą. Szkice z dziejów rewolucji francuskiej, Warszawa 1966.

${ }^{20}$ Idem, Wandea. Anatomia ludowej kontrrewolucji, Kwartalnik Historyczny, R. 74: 1967, Z. 4, s. 945-962.

${ }^{21}$ Paweł Jasienica, Rozważania o wojnie domowej, Warszawa 1978.

${ }^{22}$ Stanisław SAlmonowicz, Sylwetki spod gilotyny, Warszawa 1989.

${ }^{23}$ Emmanuel J. SiEYès, Czym jest stan trzeci? Esej o przywilejach, tł. Mikołaj JArosz, Warszawa 2016, s. 5-22.

${ }^{24}$ Zob. szerzej: Rafał STOBIECKI, Historiografia PRL. Zamiast podręcznika, Łódź 2020, s. 77 i nn.

${ }^{25} \mathrm{O}$ wpływie tej szkoły na historiografię polską lat sześćdziesiątych XX w. zob. ibid., s. 112.

${ }^{26}$ S. SAlmonowicz, „Życie jak osioł ucieka...”, s. 415 (cytat), 418.

${ }^{27}$ Idem, Wokół sporów o definicję i chronologię zjawiska Oświecenia, Czasy Nowożytne, t. 25: 2012, s. 113-138. 
Czy istniał oświecony absolutyzm w Europie XVIII wieku? ${ }^{28}$ oraz Z dziejów absolutyzmu oświeconego w Austrii ${ }^{29}$.

Odrębną domeną badawczą Profesora stały się dzieje Prus od XVIII aż po XX stulecie. Zalicza się on w tej dziedzinie do najwybitniejszych, nie tylko polskich, historyków zajmujących się tą tematyką. Trzeba tu wskazać przede wszystkim na wnikliwą, a przy tym obiektywną biografię chyba najbardziej znanego pruskiego władcy Fryderyka II Wielkiego ${ }^{30}$. Przy okazji pracy nad tą książką powstało też sporo mniejszych studiów poświęconych tak temu monarsze, jak i systemowi władzy w osiemnastowiecznych Prusach. Zwieńczeniem tych badań była obszerna synteza Prusy. Dzieje państwa i społeczeństwa ${ }^{31}$. Spotkała się ona z dużym zainteresowaniem i licznymi recenzjami, a kilka lat później ukazało się w Niemczech jej tłumaczenie ${ }^{32}$, co zostało pozytywnie odnotowane nie tylko przez historyków niemieckich, lecz także francuskich.

Historii Rzeczypospolitej w dobie wczesnonowożytnej poświęcił Stanisław Salmonowicz wprawdzie sporo swoich publikacji, ale dotyczyły one jedynie niektórych aspektów przeszłości tych ziem. Można tu wskazać przede wszystkim na problemy stosunków religijnych w kontekście słabnącej tolerancji, na różne nurty protestantyzmu i na funkcjonowanie ich wspólnot wyznaniowych (zwłaszcza pietystów), na procesy o czary i na kwestię tzw. mordów rytualnych. Znaczna część prac z tego zakresu poświęcona była sprawom polskiego oświecenia, m.in. podstawom działania Komisji Edukacji Narodowej, ówczesnemu czasopiśmiennictwu, a nawet związkom ideowym między powstaniem kościuszkowskim a rewolucją francuską. Szczególne znaczenie przypisywalibyśmy tu artykułowi Geneza i treść uchwał konfederacji warszawskiej ${ }^{33}$, w poszerzonej wersji osobno został on opublikowany jako osobna książecz$\mathrm{ka}^{34}$. Niezwykle ważny jest także artykuł Procesy o czary w Polsce. Próba rozważań modelowych ${ }^{35}$. Obie te pozycje powinny stanowić punkt wyjścia dla

${ }^{28}$ Idem, Czy istniał oświecony absolutyzm w Europie XVIII wieku?, [in:] Studia z historii ustroju i prawa. Ksiega dedykowana Profesorowi Jerzemu Walachowiczowi, red. Henryk OlszewsKI, Poznań 2002, s. 336-346.

${ }^{29}$ Idem, Z dziejów absolutyzmu oświeconego w Austrii, Czasopismo Prawno-Historyczne, t. 38: 1986, z. 1, s. 153-161.

${ }^{30}$ Idem, Fryderyk II, Wrocław 1981 (kolejne wydania: 1985, 1996, 2006).

${ }^{31}$ Idem, Prusy. Dzieje państwa i społeczeństwa, Poznań 1987 (kolejne wydania: Warszawa 1998, Warszawa 2004).

${ }^{32}$ Idem, Preußen. Geschichte von Staat und Gesellschaft, übers. v. Maria V. STEFAnski, Herne 1995.

${ }^{33}$ Idem, Geneza i treść uchwał konfederacji warszawskiej, Odrodzenie i Reformacja w Polsce, t. 19: 1974, s. 7-30.

${ }^{34}$ Idem, Konfederacja warszawska 1573, Warszawa 1985.

${ }^{35}$ Idem, Procesy o czary w Polsce. Próba rozważań modelowych, [in:] Prawo wczoraj $i$ dziś, red. Grażyna BaŁtruszajtys, Warszawa 2000, s. 303-322. 
wszystkich badaczy zajmujących się tematyką tolerancji wyznaniowej i procesów o czary w dawnej Rzeczypospolitej.

Wiele studiów Profesora chronologicznie obejmuje wiek XIX, ale przeważnie dotyczą one dziejów państwa pruskiego i jego pomorskich prowincji - Prus Zachodnich i Wschodnich. W sporej części koncentrują się też one na sprawach ustrojowo-administracyjnych. Bardziej ogólny charakter ma natomiast artykuł Rewolty ludowe, rewolucje burżuazyjne, reformy odgórne. Uwagi o trudnościach klasyfikacji ${ }^{36}$.

Podczas ostatnich czterech dziesięcioleci zainteresowania badawcze Stanisława Salmonowicza wyraźnie skoncentrowały się wokół najnowszej historii Polski (nadal kontynuuje on jednak prace także nad zagadnieniami, które wcześniej były przedmiotem jego studiów). Ten zwrot ku dziejom XX w. umożliwiły oczywiście zmiany polityczno-ustrojowe w naszym kraju. Badania Profesora $\mathrm{z}$ tego zakresu dotyczą przede wszystkim fenomenu funkcjonowania Polskiego Państwa Podziemnego w czasie okupacji (w dużej mierze zainicjował on zresztą pogłębione studia nad tą problematyką), okoliczności wybuchu powstania warszawskiego w 1944 r., dyktatury stalinowskiej w Polsce oraz złożonych postaw społeczeństwa w czasach wojny i w dobie rządów partii komunistycznej. Już w 1981 r., korzystając z pewnego zamieszania wśród władz spowodowanego pojawieniem się „Solidarności”, opublikował pod pseudonimem Antoni Nowosielski i poza zasięgiem cenzury niewielką książkę Powstanie warszawskie. Próba uporządkowania problemów genezy i oceny ogólnej. Po dziewięciu latach ukazała się ona ponownie, już pod własnym nazwiskiem autora, w znacznie poszerzonej wersji ${ }^{37}$. Później jeszcze kilkakrotnie Profesor $\mathrm{w}$ mniejszych artykułach i recenzjach nawiązywał do tego tematu.

Największym osiągnięciem badawczym Profesora z zakresu historii najnowszej jest chyba jednak obszerna monografia z 1994 r. Polskie Państwo Podziemne. Z dziejów walki cywilnej $1939-45^{38}$. Spotkała się ona z żywym oddźwiękiem wśród czytelników i w środowiskach historyków, wywołując zresztą polemiki. Drugie wydanie zostało uzupełnione o teksty Marka Ney-Krwawicza i Grzegorza Górskiego ${ }^{39}$. Temat ten jeszcze niejednokrotnie był poruszany przez Profesora w jego artykułach, publikowanych także w językach obcych.

${ }^{36}$ Idem, Rewolty ludowe, rewolucje burżuazyjne, reformy odgórne. Uwagi o trudnościach klasyfikacji, Czasopismo Prawno-Historyczne, t. 35: 1983, z. 1, s. 249-260.

${ }^{37}$ Antoni Nowosielski [Stanisław Salmonowicz], Powstanie warszawskie. Próba uporządkowania problemów genezy i oceny ogólnej, Warszawa 1981; drugie wydanie: Stanisław Salmonowicz, Powstanie warszawskie. Próba uporządkowania problemów genezy i oceny ogólnej, Toruń 1990.

${ }^{38}$ Idem, Polskie Państwo Podziemne. Z dziejów walki cywilnej 1939-45, Warszawa 1994.

${ }^{39}$ Stanisław Salmonowicz, Marek Ney-Krwawicz, Grzegorz Górski, Polskie Państwo Podziemne, Warszawa 1999. 
Zainteresowanie tą tematyką miało w przypadku Stanisława Salmonowicza w pewnej mierze podłoże rodzinne. Brat jego matki, płk Ludwik Muzyczka, był legionistą, działaczem sanacyjnego Związku Strzeleckiego, starostą, a podczas wojny szefem Administracji Zmilitaryzowanej o nazwie Szefostwo Biur Wojskowych Komendy Głównej Armii Krajowej, uczestnikiem powstania warszawskiego (decyzji o jego wywołaniu był zresztą przeciwny), a w $1945 \mathrm{r}$. jednym z inicjatorów podziemnej organizacji Wolność i Niezawisłość. W czasach stalinowskich dwukrotnie skazano go na więzienie, potem w 1957 r. zrehabilitowano. To on, jako naoczny świadek, przekazał swemu siostrzeńcowi wiele informacji (w tym i poufnych, szerzej nieznanych) o ówczesnych wydarzeniach i osobach, a także udostępnił mu zachowane materiały archiwalne z czasów konspiracji. Nic też dziwnego, że Profesor opublikował biografię swego wuja ${ }^{40}$, a stosunkowo niedawno wydał obszerną pracę zawierającą obok życiorysu płk. Muzyczki, także dokumenty z jego archiwum ${ }^{41}$.

W tym miejscu warto zwrócić uwagę na trzy mniejsze, ale niezwykle ważne, niejako prekursorskie, artykuły S. Salmonowicza, dotyczące zróżnicowanych zachowań społeczeństwa polskiego podczas drugiej wojny światowej ${ }^{42}$.

Jak już wspomnieliśmy, zainteresowania badawcze Profesora rozciągają się też na epokę powojenną. Szczególnie cenne są tu prace dotyczące postaw inteligencji polskiej w okresie stalinizmu. W jakiejś mierze odzwierciedlają one zresztą własne obserwacje autora. Można tu wskazać na dwie ważne pozycje: Profesorowie i studenci $w$ dobie stalinizmu $w$ Polsce (1944-1956) w pracy zbiorowej Polacy wobec PRL. Strategie przystosowawcze ${ }^{43}$ oraz Między strachem a manipulacja. Inteligencja polska wobec stalinizmu $u^{44}$.

Badania Stanisława Salmonowicza, po jego przeniesieniu się w $1966 \mathrm{r}$. z Krakowa do Torunia, w coraz większej mierze dotyczyły zagadnień historii

\footnotetext{
${ }^{40}$ Stanisław Salmonowicz, Ludwik Muzyczka 1900-1977. Polityk i żołnierz. Przyczynek do dziejów Armii Krajowej, Warszawa 1992.

${ }^{41}$ Idem, Ludwik Muzyczka „Benedykt” (1900-1977). Materiały historyczne do dziejów Komendy Głównej Armii Krajowej, Warszawa 2018.

${ }^{42}$ Idem, Patologie społeczne okresu okupacji hitlerowskiej, Czasy Nowożytne, t. 3: 1997, s. 5-20; idem, Tragiczna noc okupacji niemieckiej. O problematyce „kolaboracji oddolnej” w Generalnym Gubernatorstwie, Studia Iuridica Toruniensia, t. 11: 2003, s. 143-173; idem, Do Szanownego Gestapo. Rzecz o donosach z lat 1939-1945, Wiedza i Życie, 2013, nr 2, s. 24-29.

${ }^{43}$ Idem, Profesorowie $i$ studenci $w$ dobie stalinizmu w Polsce (1944-1956), [in:] Polacy wobec PRL. Strategie przystosowawcze, red. Grzegorz Miernik, Kielce 2003, s. 75-91. Do zawartych tam ogólnych, syntetycznych spostrzeżeń Profesora w swej obszernej monografii źródłowej nawiązał Tadeusz P. Rut Kowski, Nauki historyczne w Polsce 1944-1970. Zagadnienia polityczne i organizacyjne, Warszawa 2007, s. 582-583.

${ }^{44}$ Stanisław SAlmonowicz, Między strachem a manipulacją. Inteligencja polska wobec stalinizmu, Prace Komisji Historii Nauki PAU, t. 7: 2005, s. 81-104; artykuł został opublikowany także w wersji angielskiej: idem, Between Terror and Manipulation: The Polish Intelligentsia in the Face of Stalinism, Acta Poloniae Historica, vol. 100: 2009, s. 219-237.
} 
ustroju, oświaty i szeroko pojętych dziejów kultury ziem pomorskich. Studia nad dziejami Torunia koncentrowały się początkowo głównie na historii miejscowego szkolnictwa. Obok zasadniczej pracy Toruńskie Gimnazjum Akademickie $w$ latach 1681-1817 opublikował on wiele artykułów naukowych poświęconych m.in. sylwetkom toruńskich uczonych z XVII-XVIII w. Odrębne pozycje dotyczyły teatru szkolnego w Toruniu i roli toruńskich czasopism osiemnastowiecznych w rozwoju polskiej prasy, a także życiu codziennemu mieszkańców tego miasta (w tym zagrożeniu epidemiami). Bardzo często były to prace pionierskie, inspirujące do dalszych badań źródłowych nad tymi zagadnieniami. Szczególne zainteresowanie Profesor przejawiał skomplikowanymi stosunkami wyznaniowymi w Toruniu (ze szczególnym uwzględnieniem problematyki tzw. tumultu z 1724 r.), a także rolą języka polskiego w tym mieście. Znaczna część tych drobniejszych prac została zebrana w kilku wydawnictwach książkowych ${ }^{45}$. Znaczenie tych publikacji S. Salmonowicza dla poznania dziejów wewnętrznych dawnego Torunia jest bardzo duże, zwrócił on też uwagę badaczy ogólnopolskich na rolę środowisk intelektualnych Torunia w szerzeniu się myśli wczesnooświeceniowej w osiemnastowiecznej Rzeczypospolitej.

Prace nad szerzej pojętą historią Pomorza dotyczyły początkowo głównie problematyki ustroju Prus Królewskich oraz specyficznej, generalnie mieszczańskiej, kultury umysłowej tej prowincji. Szczególnie ważny i zachęcający do dalszych badań był tu artykuł $Z$ dziejów walki o tzw. restaurację autonomicznych aspiracji Prus Królewskich w XVIII wieku ${ }^{46}$. Aktywny udział w pracach nad trzecim i czwartym tomem Historii Pomorza przyniósł w efekcie znaczące poszerzenie problematyki badawczej o dzieje ziem pomorskich w XIX i początkach XX w. Powstały wówczas nowatorskie, nie tylko na gruncie polskim, studia dotyczące ustroju polityczno-administracyjnego Pomorza w ramach państwa pruskiego, kodyfikacji prawa na tych terenach, a także pruskiej warstwy urzędniczej, uchodzącej za wzorzec nowoczesnej biurokracji, jak również niektórych elementów kultury umysłowej społeczeństwa tych ziem. Po zmianach ustrojowych z 1989 r. S. Salmonowicz mógł otwarcie zajmować się tematami podlegającymi dotąd ograniczeniom cenzury. Dotyczyło to zwłaszcza organizacji podziemnych działających w Toruniu i na Pomorzu w do-

${ }^{45}$ Idem, Toruń $w$ czasach baroku i oświecenia. Szkice z dziejów kultury Torunia XVII-XVIII wieku, Warszawa 1982; idem, Myśl Oświecenia w Toruniu, Toruń 1982; idem, Szkice toruńskie z XVII-XVIII wieku, Toruń 1992; idem, W staropolskim Toruniu (XVI-XVIII w.). Studia i szkice, Toruń 2005.

${ }^{46}$ Idem, $Z$ dziejów walki o tzw. restaurację autonomicznych aspiracji Prus Królewskich w XVIII wieku, Analecta Cracoviensia, t. 7: 1975, s. 433-457. Bezpośrednio do tego artykułu nawiązuje monografia: Jerzy DygdaŁA, Życie polityczne Prus Królewskich u schyłku ich związku z Rzeczapospolita w XVIII wieku. Tendencje unifikacyjne a partykularyzm, Warszawa 1984. 
bie drugiej wojny światowej i późniejszej konspiracji niepodległościowej na tym terenie.

Zainteresowania badawcze Stanisława Salmonowicza dziejami Torunia i ziem pomorskich rozciągają się od XVI aż po schyłek XX w. Badania te w znaczącej mierze poszerzyły stan naszej wiedzy o przeszłości Torunia i całego Pomorza. Profesor zalicza się do niekwestionowanych autorytetów dla kilku już pokoleń historyków zajmujących się dziejami tego miasta i regionu. Opublikowany niedawno w języku niemieckim zbiór studiów Polnische Preussen oder Westpreussen stanowi niejako podsumowanie tego wątku badan ${ }^{47}$. Symptomatyczne, że książka ta spotkała się z entuzjastyczną wręcz recenzją we francuskim czasopiśmie „Revue historique de droit français et étranger”, a jej autorka Danielle Anex-Cabanis wręcz zasugerowała, by pracę tę przetłumaczyć na francuski, tak by tamtejsi czytelnicy przekonali się, że idee oświecenia na dalekich wschodnich peryferiach ówczesnej Europy (tak przynajmniej widziano Polskę z perspektywy Paryża) sięgały nie tylko stołecznej Warszawy, lecz także rozwijały się w Toruniu, Gdańsku i Królewcu ${ }^{48}$.

W zakresie historii prawa jedną $\mathrm{z}$ najważniejszych specjalności naukowych jubilata stanowią nowożytne kodyfikacje karne. Pierwszorzędną pracą $\mathrm{z}$ tego obszaru badawczego była niewątpliwie i nadal nią pozostaje obszerna, pełna erudycji monografia Prawo karne oświeconego absolutyzmu. $Z$ dziejów kodyfikacji karnych przełomu XVIII/XIX w. (wspomniana rozprawa habilitacyjna Stanisława Salmonowicza ${ }^{49}$. Stanowi ona syntezę ruchu kodyfikacyjnego i zarazem reformy prawa karnego, zainicjowanych w Europie w drugiej połowie XVIII stulecia. Wyjątkowa wartość tej książki polega na przedstawieniu reform kodyfikacyjnych w różnych krajach - od Włoch przez Austrię i Prusy aż po Rosję, nie mówiąc o uwagach porównawczych na temat Francji i Bawarii. Autor oparł swoje analizy na wielojęzycznej literaturze przedmiotu. Monografia ta nadal jest kanonem dla historyków prawa karnego oraz przedstawicieli nauk penalnych.

Fundamentalny charakter ma również artykuł poświęcony pierwszym kodeksom we współczesnym tego słowa znaczeniu, analizujący ich genezę oraz oceniający poziom ówczesnych rozwiązań techniczno-redakcyjnych ${ }^{50}$. Eksplorację tego obszaru badawczego rozpoczął Profesor już w latach sześćdziesią-

${ }^{47}$ Stanisław Salmonowicz, Polnische Preussen oder Westpreussen. Ausgewählte Studien, übers. v. Magdalena DARSKA-Łogin, Gdańsk-Toruń 2018.

${ }^{48}$ Danielle Anex-Cabanis, [rec.] Stanisław Salmonowicz, Polnische Preussen oder Westpreussen. Ausgewählte Studien, Revue historique de droit français et étranger, 2020, no. 1, s. 78.

${ }^{49}$ Zob. przyp. 7.

${ }^{50}$ Stanisław SAlmonowicz, Narodziny nowożytnej myśli kodyfikacyjnej w Europie, Czasopismo Prawno-Historyczne, t. 29: 1977, z. 1, s. 77-104. 
tych XX w. ${ }^{51}$ Badania tego rodzaju kontynuował przez kilkadziesiąt lat, poszerzając zresztą ich ramy chronologiczne aż po wiek XIX ${ }^{52}$. Nawet w ostatnim okresie nieraz jeszcze powracał myślą i piórem do technicznej strony dawnego i nowszego procesu kodyfikacyjnego ${ }^{53}$ oraz do nowoczesnych kodyfikacji karnych $^{54}$. Niejeden tekst poświęcił najbardziej znanemu kodeksowi karnemu początku czasów nowożytnych - niemieckiej Carolinie ${ }^{55}$. Zajął się również szczególnymi aktami prawnymi wydawanymi w epoce absolutyzmu i absolutyzmu oświeconego - tzw. ordynacjami stosowanymi na ziemiach niemieckich w zakresie polityki społecznej i ekonomicznej państwa ${ }^{56}$.

Profesor Salmonowicz badał wreszcie ustawodawstwo partykularne, czego najlepszym przykładem są jego dogłębne opracowania na temat odrębnych, regionalnych kodyfikacji wydanych w monarchii Hohenzollernów w prowincjach Prusy Wschodnie (byłe Prusy Książęce) i Prusy Zachodnie (byłe Prusy Królewskie). Przedstawiając je, autor poświęcił baczną uwagę roli tradycyjnego na tych terytoriach prawa chełmińskiego, które stanowiło podstawę wolności politycznych ludności miast ${ }^{57}$. Warto w tym miejscu przypomnieć, że wiele regulacji dawnego prawa chełmińskiego zachowało się jeszcze w zbiorze praw prowincji Prusy Zachodnie, wydanym w 1844 r., co autor jasno wykazał.

Niemal od początku swojej działalności naukowej Stanisław Salmonowicz powiązał zainteresowania badawcze dziejami kodyfikacji z analizą humanitarnej reformy prawa karnego doby oświecenia. Te prace badawcze przyniosły bogate owoce w postaci szeregu artykułów charakteryzujących przede wszystkim postać i dorobek wybitnego włoskiego osiemnastowiecznego prawnika i filozofa Cesarego Beccarii, znanego rzecznika reformy prawa i procesu karnego

${ }^{51}$ Stanisław Salmonowicz, Stanisław Grodziski, Ustawa karna zachodniogalicyjska $z$ roku 1796. Zarys dziejów i charakterystyka, Czasopismo Prawno-Historyczne, t. 17: 1965, z. 2, s. $125-149$.

${ }^{52}$ Stanisław Salmonowicz, Penal Codes of the $16^{\text {th }}-19^{\text {th }}$ Centuries: A Discussion of Models, Comparative Law Review, vol. 2: 1991, s. 123-137.

${ }^{53}$ Idem, O badaniach nad dziejami techniki legislacyjnej $w$ Europie średniowiecza $i$ w czasach nowożytnych, Miscellanea Historico-Iuridica, t. 13: 2014, z. 1, s. 237-252.

${ }^{54}$ Idem, Europa 1777 r. Od humanitarnej krytyki prawa obowiązującego po budowe nowych kodeksów karnych, Studia Iuridica Toruniensia, t. 20: 2017, s. 269-297.

${ }^{55}$ Wspomnijmy tu: idem, Wizerunek kodeksu. Constitutio Criminalis Carolina, Roczniki Nauk Prawnych, t. 13: 2003, nr 1, s. 53-66.

${ }^{56}$ Idem, Niemieckie ordynacje policyjne (XVI-XVIII wiek). Uwagi o sytuacji badawczej, Czasy Nowożytne, t. 23: 2010, s. 151-177.

${ }^{57}$ Do najważniejszych tekstów w tym zakresie należą: idem, $Z$ dziejów wschodniopruskich kodyfikacji prowincjonalnych (XVII-XIX w.). Przyczynek do losów prawa chetmińskiego w państwie brandenbursko-pruskim, [in:] Studia Culmensia Historico-Juridica czyli Księga pamiątkowa 750-lecia prawa chełmińskiego, t. 2, red. Zbigniew ZDRójKowski, Toruń 1988, s. 271-326; idem, Prawo prowincjonalne Prus Zachodnich i sprawa jego kodyfikacji (1772-1844), Zapiski Historyczne, t. 45: 1980, z. 2, s. 25-59. 
w duchu humanitarnym. Wyjątkową okazją dla przypomnienia jego myśli i wpływów była dwusetna rocznica śmierci wybitnego Włocha, przypadająca w 1994 r. Z inicjatywy prof. Salmonowicza odbyła się wtedy konferencja naukowa, której rezultatem stał się zredagowany przez niego tom pokonferencyjny Cesare Beccaria (1738-1794) - reformator prawa karnego i jego epoka ${ }^{58}$. Za tym opracowaniem przyszły kolejne ${ }^{59}$. Stanisław Salmonowicz nie zapomniał o upowszechnieniu za granicą dorobku polskich reformatorów prawa, nie tylko karnego, epoki oświecenia ${ }^{60}$. Z kolei artykuł na temat roli prawa rzymskiego w Rzeczypospolitej epoki oświecenia był swego czasu jednym z pierwszych ujęć tego typu ${ }^{61}$.

Nie wahał się wreszcie S. Salmonowicz przed wyrażeniem swojego stosunku do fundamentalnej kwestii prawa karnego - kary śmierci, traktowanej aż do drugiej połowy XX w. jako ultima ratio porządku prawnego w Polsce i Europie. Stąd pojawily się jego liczne teksty historycznoprawne oraz publicystyczne na ten temat ${ }^{62}$. Niezwykle interesującym wątkiem badawczym w ramach historii prawa były dla niego procesy o czary. Już w $1961 \mathrm{r}$. opublikował on pierwszy przyczynek na ten temat ${ }^{63}$, a w następnych latach pogłębiał problematykę ${ }^{64}$.

${ }^{58}$ Idem, Cesare Beccaria na tle literatury humanitarnej XVIII wieku, [in:] Cesare Beccaria (1738-1794) - reformator prawa karnego i jego epoka. Materialy sesji naukowej zorganizowanej przez Wydział Prawa i Administracji UMK w Toruniu i Towarzystwo Naukowe w Toruniu w dniu 29 marca 1994 r., red. Stanisław Salmonowicz, Torun 1995, s. 9-33.

${ }^{59}$ Idem, Cesare Beccaria (1738-1794). Sylwetka i dzieło, Analecta. Studia i Materiały z Dziejów Nauki, t. 5: 1995, z. 2, s. 9-27; idem, Kilka uwag o recepcji Cezarego Beccarii (1738-1794) jako karnisty w Polsce. Uwagi w dwusetlecie zgonu, [in:] Dawne prawo i myśl prawnicza. Prace historyczno-prawne poświęcone pamięci Wojciecha Marii Bartla, red. Jerzy MaLEC, Wacław URUSZCZAK, Kraków 1995, s. 163-170.

${ }^{60}$ Idem, Les vicissitudes de la réforme pénale en Pologne du XVIIIe siècle, [in:] Le politiche criminali nel XVIII secolo, cur. Luigi BerLINGuer, Floriana Colao, Milano 1990, s. 461-484.

${ }^{61}$ Idem, Le droit romain en Pologne à lépoque des Lumières, [in:] Studi in onore di Edoardo Volterra, vol. 2, Milano 1971, s. 351-370.

${ }^{62}$ Idem, Śmierć nie zawsze w majestacie prawa. Z dziejów kary śmierci w krajach niemieckich, Czasopismo Prawno-Historyczne, t. 49: 1997, z. 1-2, s. 321-337; idem, Józefa Soltykowicza (1762-1831) mowa przeciw karze śmierci z 1818 roku. Przyczynek do dziejów polskiego abolicjonizmu, [in:] Profesorowi Janowi Kodrębskiemu in memoriam, red. Anna Pikulska-RobaszKiewICz, Łódź 2000, s. 339-348; idem, Cesare Beccaria, kara śmierci i wspótczesny terroryzm, [in:] Nam hoc natura aequum est... Księga jubileuszowa ku czci profesora Janusza Justyńskiego w siedemdziesięciolecie urodzin, red. Andrzej MADEJA, Toruń 2012, s. 131-140; idem, Kara śmierci jest nade wszystko niebezpieczna, Ład, R. 8: 1990, nr 2, s. 14-15.

${ }^{63}$ Idem, Z problematyki procesów o czary. Uwagi na marginesie najnowszej literatury, Czasopismo Prawno-Historyczne, t. 13: 1961, z. 2, s. 209-221.

${ }^{64}$ Idem, O niegodziwości procesów o czary, Czasopismo Prawno-Historyczne, t. 46: 1994, z. 1-2, s. 115-120; idem, Vom Unfug der Hexenprozesse, Acta Poloniae Historica, vol. 74: 1996, s. 173-180; idem, O procesach o czary w Polsce, Czasy Nowożytne, t. 21: 2008, s. 195-218; idem, O procesach o czary w „Prusach Brandenburskich”, Czasy Nowożytne, t. 20: 2007, s. 299-311. 
O kontekście tych badań była już mowa. W tym miejscu natomiast trzeba odnotować, że S. Salmonowicz od początku swojej twórczości dbał nie tylko o prace naukowo-badawcze nad historią nowożytnego prawa karnego, lecz także o popularyzację ich wyników. Największym sukcesem okazał się jego udział, jako współautora, we wspomnianej już książce Pitaval krakowski ${ }^{65}$, w którym znalazły się opisy autentycznych głośnych procesów kryminalnych z podwawelskiego grodu.

Stanisław Salmonowicz jest zatem, jak wynika z powyższego, znakomitym znawcą dziejów kodyfikacji prawa. Dokładnie to samo można powiedzieć o jego znajomości dziejów nauki prawa w Polsce. Warsztat i biegłość w tym ostatnim zakresie przyniosła mu trzyletnia praca nad doktoratem, napisanym pod opieką prof. Karola Koranyiego. Był on poświęcony, jak wspomnieliśmy, Krystianowi Bogumiłowi Steinerowi, prawnikowi i ważnej postaci polskiego oświecenia $^{66}$. Praca doktorska S. Salmonowicza stanowiła jednak nade wszystko znakomitą książkę $\mathrm{z}$ historii nauki, a jednocześnie umacniała zainteresowania naukowe jej autora szeroko pojętą kulturą wieku oświecenia.

Zakres chronologiczny badań Profesora nad historią nauki prawa jest imponujący, albowiem rozciąga się na cztery stulecia. Mieszczą się w nim, po pierwsze, opracowania na temat doktryny prawa XVII-XVIII w. ${ }^{67}$ Po drugie, S. Salmonowicz wypowiadał się niejednokrotnie na temat polskiej nauki prawa dwudziestolecia międzywojennego ${ }^{68}$. Po trzecie, wielokrotnie przedstawiał postawy i dorobek przedstawicieli nauki prawa oraz nauki historii prawa Polski Ludowej ${ }^{69}$. Nie zabrakło w tych rozważaniach miejsca na wszechstronną prezentację wyjątkowej, legendarnej postaci Karola Koranyiego (zresztą

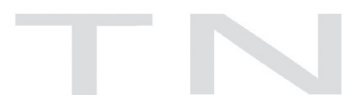

${ }^{65}$ Stanisław SAlmonowicz, Janusz SzwaJA, Stanisław WALtoś, Pitaval krakowski, Warszawa 1962.

${ }^{66}$ Zob. przyp. 6.

${ }^{67}$ Stanisław SAlmonowicz, Rechtslehre und Rechtswissenschaft am Thorner Gymnasium Academicum im 17. Jahrhundert, [in:] Europa in der Frühen Neuzeit. Festschrift für Günter Mühlpfordt, Bd. 3, hrsg. v. Erich Donnert, Köln-Weimar-Wien 1997, s. 485-493; idem, Maciej Nizolius (1568?-1608), rektor toruńskiego gymnasium academicum, wykładowca prawa rzymskiego, [in:] Leges sapere. Studia i prace dedykowane Profesorowi Januszowi Sondlowi w pięćdziesiąta rocznicę pracy naukowej, red. Wacław Uruszczak, Paulina ŚwięcickA, Andrzej Kremer, Kraków 2008, s. 485-497; idem, Franciszek Minocki (1730-1784) jako pisarz prawa karnego, [in:] Miscellanea iuridica złożone $w$ darze Karolowi Koranyiemu w czterdziestolecie pracy naukowej, red. Krystyna Buкоwska [et al.], Warszawa 1961, s. 121-146.

${ }^{68}$ Wystarczy wspomnieć artykuł: idem, O dziejach Wydziału Prawa UJ w dobie II RP, Krakowskie Studia z Historii Państwa i Prawa, t. 10: 2017, z. 2, s. 137-149.

${ }^{69}$ Problematyka ta została przez niego podjęta m.in. w artykule: Profesorowie $i$ studenci $w$ dobie stalinizmu $w$ Polsce (zob. przyp. 43); idem, Historia prawa wobec II RP. Uwagi o stanie badań, Studia Iuridica Toruniensia, t. 18: 2016, s. 9-28. 
krótko rektora UMK), zwłaszcza zaś jego imponującego dorobku z niezrównanym podręcznikiem z powszechnej historii państwa i prawa na czele ${ }^{70}$.

Wyjątkowy charakter ma oryginalne i doniosłe merytorycznie studium S. Salmonowicza w pracy zbiorowej zatytułowanej Wkład osiagnięć polskiej nauki i techniki do dziedzictwa światowego. Autor włączył do niej istotny rozdział pt. Wkład polskiej nauki prawa do światowego dziedzictwa ${ }^{71}$. Swoistym podsumowaniem, a zarazem drogowskazem dla następnych badaczy są oceny i zalecenia Profesora zawarte w artykule podsumowującym stan badań, zatytułowanym O dziejach nauki prawa w Polsce. Problemy i perspektywy badawcze $e^{72}$.

Całkowicie odmiennym kierunkiem twórczości naukowej S. Salmonowicza jest historia ustroju Polski, w ramach której badał on i prezentował przede wszystkim dzieje najnowsze. O jego książkach i artykułach na temat Polskiego Państwa Podziemnego (1939-1945), których wydawanie zapoczątkował już na początku lat osiemdziesiątych XX w., a znacząco rozwinął po transformacji ustrojowej naszego kraju, publikując przełomowe dla tej problematyki prace, była już szerzej mowa. W tym miejscu wspomnijmy natomiast o najnowszych i pionierskich badaniach Profesora na temat statusu prawnego obywatela polskiego pod okupacją hitlerowską, których owocem stał się oryginalny artykuł Status prawny Polaka pod okupacja niemiecka (1939-1945). Uwagi o potrzebie badań, opublikowany następnie po angielsku ${ }^{73}$.

Jednocześnie przez wiele lat S. Salmonowicz zajmował się ustrojem i prawem publicznym dawnej Polski - wystarczy tu przypomnieć jego teksty poświęcone problematyce ustrojowej Rzeczypospolitej Obojga Narodów oraz rezultatom działalności Sejmu Czteroletniego, w tym Konstytucji 3 maja ${ }^{74}$.

${ }^{70}$ Wskazać tu trzeba przede wszystkim: idem, Karol Koranyi (1897-1964), historyk prawa, [in:] Ze złotej księgi Wydziału Prawa i Administracji Uniwersytetu Mikołaja Kopernika, red. Stanisław Salmonowicz, Marek Soвсzyк, Toruń 2015, s. 36-69; idem, Karola Koranyiego wielki podręcznik powszechnej historii prawa, [in:] Karol Koranyi (1897-1964). Studia w stulecie urodzin, red. Stanisław Salmonowicz, Toruń 1998, s. 53-64.

${ }^{71}$ Idem, Wkład polskiej nauki prawa do światowego dziedzictwa, [in:] Wkład osiagnięć polskiej nauki i techniki do dziedzictwa światowego, red. Irena STASIEWICZ-Jasıukowa, Warszawa-Kraków 2009, s. 305-321.

${ }^{72}$ Idem, O dziejach nauki prawa w Polsce. Problemy i perspektywy badawcze, Czasopismo Prawno-Historyczne, t. 50: 1998, z. 1, s. 235-240.

${ }^{73}$ Idem, Status prawny Polaka pod okupacja niemiecka (1939-1945). Uwagi o potrzebie badań, Krakowskie Studia z Historii Państwa i Prawa, t. 9: 2016, z. 3, s. 345-360; w wersji angielskojęzycznej: idem, The Legal Status of Poles under German Occupation (1939-1945): Some Remarks on the Need for Research, Krakowskie Studia z Historii Państwa i Prawa, 2017, zeszyt specjalny, s. 95-110.

${ }^{74}$ Wymieńmy najważniejsze: idem, Cezura roku 1569. Z problematyki periodyzacji ustroju dawnej Rzeczpospolitej, [in:] O prawie i jego dziejach ksieggi dwie. Studia ofiarowane profesorowi Adamowi Lityńskiemu w czterdziestolecie pracy naukowej i siedemdziesięciolecie urodzin, ks. 1, red. Marian МıкоєАјсZук [et al.], Białystok 2010, s. 359-366; idem, Konfederacja warszawska, 
Znaczące miejsce zajmuje w tych badaniach status prowincji Prusy Królewskie, prezentowany w kilku opracowaniach ${ }^{75}$.

Także historia ustroju Europy, zwłaszcza zaś przemiany i charakter rządów na ziemiach niemieckich oraz we Francji, zajmowały uwagę prof. Salmonowicza. Owocem prowadzonych przez niego wieloletnich badań stały się książki i artykuły, z klasycznym dziełem Prusy. Dzieje państwa i społeczeństwa na czele. O kontekście jego opracowania i znaczeniu powiedzieliśmy już wcześniej. Ulubionymi okresami historycznymi S. Salmonowicza były epoka absolutyzmu oraz czas rewolucji francuskiej. O tych tematach w jego twórczości była już mowa; teraz wszakże pragniemy podkreślić, że Profesor jest niewątpliwie jednym z najlepszych polskich znawców problematyki ustroju absolutystycznego, przede wszystkim jego specyficznej formy, jaką był absolutyzm oświecony.

Znawstwo w zakresie historii ustrojów państwowych zaowocowało wreszcie podręcznikami akademickimi, wydawanymi we współautorstwie, w szczególności popularną, kilkakrotnie wydawaną Historiq ustroju Polski, której współautorem był Ryszard Łaszewski ${ }^{76}$, a także Historia ustrojów państw napisaną przy współautorstwie Grzegorza Górskiego ${ }^{77}$.

Profesor Stanisław Salmonowicz, autor tak licznych opracowań z historii ruchu kodyfikacyjnego oraz humanitarnego, a także dziejów nauki prawa i sądownictwa, podjął w ostatnich latach słuszną i chwalebną decyzję o systematycznej publikacji swoich ważnych, ale rozproszonych w różnych dawnych czasopismach czy wydawnictwach zbiorowych, specjalistycznych tekstów - w formie osobnych tomików. W ten sposób zebrał i wydał kilka książek - zbiorów studiów z historii państwa, prawa oraz spraw społeczno-politycznych różnych epok.

passim; idem, Ludzie i dzieło Sejmu Czteroletniego, Toruń 1988; idem, Les droits de l'homme dans la Constitution du 3. Mai 1791 et la tradition des libertés de la noblesse polonaise, [in:] The Origin of Human Rights: The Constitution of 3 May 1791, the French Declaration of Rights, the Bill of Rights: Proceedings at the Seminar Held at the Nicolaus Copernicus University, May 3-5, 1991, ed. Janusz L. JustYŃski, Toruń 1991, s. 59-68.

${ }^{75}$ Idem, Prusy Królewskie w ustroju Rzeczypospolitej szlacheckiej (1569-1772), [in:] Studia $z$ dziejów Rzeczypospolitej szlacheckiej, red. Krystyn Matwijowsкi, Zbigniew Wójcıк, Wrocław 1988, s. 45-57; idem, Prusy Królewskie w Rzeczypospolitej polsko-litewskiej. Uwagi porównawcze, [in:] Rzeczpospolita wielu narodów i jej tradycje. Materiały z konferencji „Trzysta lat od początku unii polsko-saskiej. Rzeczypospolita wielu narodów i jej tradycje”, Kraków 15-17 IX 1997 r., red. Andrzej K. Link-Lenczowski, Mariusz Markiewicz, Kraków 1999, s. 115-123; idem, Prusy Królewskie w strukturach Rzeczypospolitej (1569-1772), [in:] Rzeczpospolita w XVI-XVIII wieku. Państwo czy wspólnota?, red. Bogusław Dybaś, Paweł Hanczewski, Tomasz Kempa, Toruń 2007, s. 159-167.

${ }^{76}$ Ryszard Łaszewski, Stanisław Salmonowicz, Historia ustroju Polski, Toruń 1995.

${ }^{77}$ Grzegorz GóRSKi, Stanisław Salmonowicz, Historia ustrojów państw, Warszawa 2001. 
W zbiorze Z wieku Oświecenia. Studia z dziejów prawa i polityki XVIII wie$k u$ znalazły się rozprawy na temat ruchu humanitarnego i kodyfikacyjnego epoki oświecenia oraz rewolucji, w tym zwłaszcza rewolucji burżuazyjnej we Francji ${ }^{78}$. W następnym wyborze Studia $z$ historii prawa (XVI-XX wiek) autor przypomniał m.in. swoje naukowe eseje na temat spraw politycznych, społecznych i prawnych Polski międzywojennej oraz Polskiego Państwa Podziemnego okresu okupacji hitlerowskiej ${ }^{79}$. Książka W cieniu Klio i Temidy. Studia $z$ historii prawa odświeżyła wiedzę o ważnych problemach porządku publicznego i prawnego dawnej Polski, tj. polsko-litewskiej Rzeczypospolitej, funkcjonowaniu Polskiego Państwa Podziemnego oraz dziejach nauki prawa w pierwszych latach Polski Ludowej ${ }^{80}$. W ramach tego ostatniego tematu autor przypomniał, obok znanego prof. Karola Koranyiego, nieco zapomnianą postać swojego naukowego mistrza, czyli prof. Michała Patkaniowskiego ${ }^{81}$. W zbiorze Od XVI do XX wieku. Studia historyczne i historycznoprawne znalazły się, nieprzypadkowo dobrane, rozprawy $z$ historii stosunków wyznaniowych, zagadnień kodyfikacyjnych i problematyki Oświecenia, a ponadto z dziejów najnowszych - spraw II Rzeczypospolitej, okupacji niemieckiej i sowieckiej, a także historii powojennej ${ }^{82}$. W'śród tych licznych zbiorów studiów S. Salmonowicza na szczególną uwagę zasługuje wspomniany już niemieckojęzyczny wybór Polnische Preussen oder Westpreussen, w którym znalazł się fachowy tekst o nauce prawa w toruńskim gimnazjum protestanckim.

Wybory prac Profesora stanowią inspirującą lekturę dla każdego miłośnika historii, zarówno tej polskiej, jak i europejskiej; są również ważną pozycją bibliograficzną dla studentów historii, prawa oraz innych kierunków humanistycznych lub społecznych.

Analizując publikacje naukowe Stanisława Salmonowicza, można zauważyć, że mają one różny charakter. Są wśród nich podstawowe monografie źródłowe przynoszące nową faktografię. Można tu wskazać na prace dotyczące m.in. prawnika Krystiana Bogumiła Steinera, toruńskiego Gimnazjum Akademickiego, kodyfikacji karnych oświeconego absolutyzmu czy Polskiego Państwa Podziemnego i powstania warszawskiego oraz biografię Ludwika $\mathrm{Mu}$ zyczki. W nurcie tym mieści się także znacząca liczba artykułów poświęconych kulturze dawnego Torunia, sprawom ustrojowym i wyznaniowym szlacheckiej

${ }^{78}$ Stanisław Salmonowicz, Z wieku Oświecenia. Studia z dziejów prawa i polityki XVIII wieku, Toruń 2001.

${ }^{79}$ Idem, Studia $z$ historii prawa (XVI-XX wiek), Bydgoszcz 2010.

${ }^{80}$ Idem, W cieniu Klio i Temidy. Studia z historii prawa, Torun 2011.

${ }^{81}$ Idem, Michał Patkaniowski (1907-1972). Przyczynek do dziejów Wydziału Prawa i Administracji UJ, [in:] idem, W cieniu Klio i Temidy. Studia z historii prawa, Toruń 2011, s. 105-140.

${ }^{82}$ Idem, Od XVI do XX wieku. Studia historyczne i historycznoprawne, red. Danuta JanICKA, Toruń 2016. 
Rzeczypospolitej (w tym Prus Królewskich), wreszcie historii prawa. Niezależnie od tego można wyróżnić w twórczości Profesora sporo książek i mniejszych prac o charakterze syntetycznym, podsumowujących dotychczasowy dorobek historiografii, przy czym sposób przedstawienia niektórych problemów jest wyraźnie nowatorski. Wystarczy tu wskazać na biografię Fryderyka Wielkiego, dzieje państwa pruskiego i obszerne fragmenty syntetycznych ujęć historii Torunia i dziejów Pomorza. Wśród prac S. Salmonowicza spotykamy także wiele pozycji, które mogą stanowić inspirację do dalszych badań (chociażby nad problematyką procesów o czary lub wątpliwych moralnie postaw części ludności polskiej wobec okupantów w czasie drugiej wojny światowej), przy czym niezwykła erudycja autora pozwala mu swobodnie obracać się w kręgu różnorodnych tematów.

Podsumowując, pragniemy raz jeszcze podkreślić, że twórczość Stanisława Salmonowicza cechuje niezrównana, godna pozazdroszczenia wszechstronność. Długo można byłoby debatować nad jej źródłami. Wydaje się, że ta różnokierunkowość wynika przede wszystkim z ciekawości świata i historii, tej polskiej i tej europejskiej, a $\mathrm{w}$ ich ramach $-\mathrm{z}$ autentycznej fascynacji procesami rozwoju państwa, społeczeństwa i prawa. Nie możemy także nie wspomnieć, że Profesora cechuje bezkonkurencyjna wprost pracowitość, wyniesiona z domu i ze szkoły, rozwinięta podczas studiów wyższych, doktoranckich i zagranicznych, kultywowana do dziś. To ona, jak się można domyślać, pozwala Stanisławowi Salmonowiczowi działać od niemal 70 lat w duchu powiedzenia francuskiego poety Stéphane Mallarmé: „Le monde est fait pour aboutir à un beau livre".

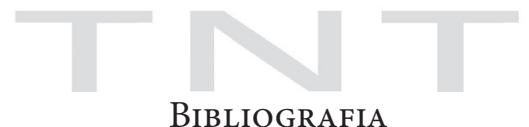

Anex-Cabanis, Danielle. Review of Polnische Preussen oder Westpreussen. Ausgewählte Studien, by Stanisław Salmonowicz. Revue historique de droit français et étranger (2020) issue 1: 78.

Backvis, Claude. Le dramaturge Stanislas Wyspiański (1869-1907). Paris: Presses Universitaires de France, 1952.

Biskup, Marian, ed. Wybitni ludzie dawnego Torunia. Warszawa: Państwowe Wydawnictwo Naukowe, 1982.

Borzyszkowski, Józef [et al.], eds. Wybitni Pomorzanie XVIII wieku. Szkice biograficzne. Gdańsk, Wrocław: Zakład Narodowy im. Ossolińskich, 1983.

Dygdała, Jerzy. "Badania Stanisława Salmonowicza nad historią Torunia i Pomorza." In Historia integra. Ksiega pamiątkowa ofiarowana prof. Stanisławowi Salmonowiczowi w siedemdziesięciolecie urodzin, edited by Jerzy Dygdała [et al.], 15-17. Toruń: TNOiK „Dom Organizatora”, 2001. 
Jerzy Dygdała [et al.], eds. Historia integra. Księga pamiątkowa ofiarowana prof. Stanisławowi Salmonowiczowi w siedemdziesięciolecie urodzin. Toruń: TNOiK „Dom Organizatora”, 2001.

Dygdała, Jerzy. Życie polityczne Prus Królewskich u schyłku ich związku z Rzecząpospolita w XVIII wieku. Tendencje unifikacyjne a partykularyzm. Warszawa: Państwowe Wydawnictwo Naukowe, 1984.

Górski, Grzegorz. "Stanisław Salmonowicz jako badacz historii XX stulecia." In $\mathrm{Hi}$ storia integra. Ksiega pamiątkowa ofiarowana prof. Stanisławowi Salmonowiczowi $w$ siedemdziesięciolecie urodzin, edited by Jerzy Dygdała [et al.], 23-25. Toruń: TNOiK „Dom Organizatora”, 2001.

Górski, Grzegorz and Stanisław Salmonowicz. Historia ustrojów państw. Warszawa: Wydawnictwo Prawnicze LexisNexis, 2001.

Janicka, Danuta. "Wiek XVIII i XIX w twórczości naukowej Profesora Salmonowicza." In Historia integra. Ksiega pamiatkowa ofiarowana prof. Stanisławowi Salmonowiczowi w siedemdziesięciolecie urodzin, edited by Jerzy Dygdała [et al.], 19-22. Toruń: TNOiK „Dom Organizatora”, 2001.

Jasienica, Paweł. Rozważania o wojnie domowej. Warszawa: Niezależna Oficyna Wydawnicza, 1978.

Łaszewski, Ryszard. "Profesor Stanisław Salmonowicz - biografia naukowa." In $\mathrm{Hi}$ storia integra. Ksiega pamiatkowa ofiarowana prof. Stanisławowi Salmonowiczowi w siedemdziesięciolecie urodzin, edited by Jerzy Dygdała [et al.], 11-14. Toruń: TNOiK „Dom Organizatora”, 2001.

Łaszewski, Ryszard and Stanisław Salmonowicz. Historia ustroju Polski. Toruń: TNOiK „Dom Organizatora”, 1995.

Mikulski, Krzysztof, ed. Toruński słownik biograficzny, vol. 1-3. Toruń: Towarzystwo Miłośników Torunia, Uniwersytet Mikołaja Kopernika, 1998-2000.

Nowosielski, Antoni [Stanisław Salmonowicz]. Powstanie warszawskie. Próba uporządkowania problemów genezy i oceny ogólnej. Warszawa: Wydawnictwo Krąg, 1981.

Rutkowski, Tadeusz P. Nauki historyczne w Polsce 1944-1970. Zagadnienia polityczne i organizacyjne. Warszawa: Wydawnictwa Uniwersytetu Warszawskiego, 2007.

Salmonowicz, Stanisław. "Between Terror and Manipulation: The Polish Intelligentsia in the Face of Stalinism." Acta Poloniae Historica 100 (2009): 219-237.

Salmonowicz, Stanisław. "Cesare Beccaria (1738-1794). Sylwetka i dzieło." Analecta. Studia i Materiały z Dziejów Nauki 5/2 (1995): 9-27.

Salmonowicz, Stanisław. “Cesare Beccaria, kara śmierci i współczesny terroryzm.” In Nam hoc natura aequum est... Ksiegga jubileuszowa ku czci profesora Janusza Justyńskiego w siedemdziesięciolecie urodzin, edited by Andrzej Madeja, 131-140. Toruń: TNOiK „Dom Organizatora”, 2012.

Salmonowicz, Stanisław. "Cesare Beccaria na tle literatury humanitarnej XVIII wieku." In Cesare Beccaria (1738-1794) - reformator prawa karnego i jego epoka. Materiały sesji naukowej zorganizowanej przez Wydziat Prawa i Administracji UMK w Toruniu $i$ Towarzystwo Naukowe w Toruniu $w$ dniu 29 marca 1994 r., edited by Stanisław Salmonowicz, 9-33. Toruń: Towarzystwo Naukowe w Toruniu, 1995.

Salmonowicz, Stanisław. "Cezura roku 1569. Z problematyki periodyzacji ustroju dawnej Rzeczpospolitej." In O prawie i jego dziejach ksiegi dwie. Studia ofiarowane 
profesorowi Adamowi Lityńskiemu w czterdziestolecie pracy naukowej i siedemdziesięciolecie urodzin, vol. 1, edited by Marian Mikołajczyk [et al.], 359-366. Białystok: Wydawnictwo Uniwersytetu w Białymstoku, 2010.

Salmonowicz, Stanisław. "Czy istniał oświecony absolutyzm w Europie XVIII wieku?" In Studia $z$ historii ustroju i prawa. Ksiega dedykowana Profesorowi Jerzemu Walachowiczowi, edited by Henryk Olszewski, 336-346. Poznań: Printer, 2002.

Salmonowicz, Stanisław. "Europa 1777 r. Od humanitarnej krytyki prawa obowiązującego po budowę nowych kodeksów karnych.” Studia Iuridica Toruniensia 20 (2017): 269-297.

Salmonowicz, Stanisław. "Franciszek Minocki (1730-1784) jako pisarz prawa karnego." In Miscellanea iuridica złożone $w$ darze Karolowi Koranyiemu w czterdziestolecie pracy naukowej, edited by Krystyna Bukowska [et al.], 121-146. Warszawa: Państwowe Wydawnictwo Naukowe, 1961.

Salmonowicz, Stanisław. Francja pod jakobińska gwiazdą. Szkice z dziejów rewolucji francuskiej. Warszawa: Wiedza Powszechna, 1966.

Salmonowicz, Stanisław. Fryderyk II. Wrocław: Zakład Narodowy im. Ossolińskich, 1981.

Salmonowicz, Stanisław. Gawędy o ludziach i książkach. Felietony publikowane w miesięczniku 'Pomerania' w latach 2013-2019. Edited by Maciej J. Mazurkiewicz. Gdańsk: Wydawnictwo Zrzeszenia Kaszubsko-Pomorskiego, 2019.

Salmonowicz, Stanisław. "Geneza i treść uchwał konfederacji warszawskiej." Odrodzenie i Reformacja w Polsce 19 (1974): 7-30.

Salmonowicz, Stanisław. "Historia prawa wobec II RP. Uwagi o stanie badań." Studia Iuridica Toruniensia 18 (2016): 9-28.

Salmonowicz, Stanisław. "Jak studiowałem w dobie polskiego stalinizmu." Analecta. Studia i Materiały z Dziejów Nauki 11/1-2 (2002): 313-336.

Salmonowicz, Stanisław. "Józefa Sołtykowicza (1762-1831) mowa przeciw karze śmierci z 1818 roku. Przyczynek do dziejów polskiego abolicjonizmu.” In Profesorowi Janowi Kodrębskiemu in memoriam, edited by Anna Pikulska-Robaszkiewicz, 339-348. Łódź: Wydawnictwo Uniwersytetu Łódzkiego, 2000.

Salmonowicz, Stanisław. "Karol Koranyi (1897-1964), historyk prawa." In Ze złotej ksiegi Wydziału Prawa i Administracji Uniwersytetu Mikołaja Kopernika, edited by Stanisław Salmonowicz and Marek Sobczyk, 36-69. Toruń: Wydawnictwo Naukowe Uniwersytetu Mikołaja Kopernika, 2015.

Salmonowicz, Stanisław. "Karola Koranyiego wielki podręcznik powszechnej historii prawa." In Karol Koranyi (1897-1964). Studia w stulecie urodzin, edited by Stanisław Salmonowicz, 53-64. Toruń: Wydawnictwo Uniwersytetu Mikołaja Kopernika, 1998.

Salmonowicz, Stanisław. "Kilka uwag o recepcji Cezarego Beccarii (1738-1794) jako karnisty w Polsce. Uwagi w dwusetlecie zgonu.” In Dawne prawo i myśl prawnicza. Prace historyczno-prawne poświęcone pamięci Wojciecha Marii Bartla, edited by Jerzy Malec and Wacław Uruszczak, 163-170. Kraków: Uniwersytet Jagielloński, 1995.

Salmonowicz, Stanisław. Konfederacja warszawska 1573. Warszawa: Zamek Królewski, 1985. 
Salmonowicz, Stanisław. “Krakowskie 'prehistoryjki opozycyjne’ lat 1956-1966." Arcana 68/2 (2006): 70-99.

Salmonowicz, Stanisław. Krystian Bogumił Steiner (1746-1814), toruński prawnik i historyk. Studium z dziejów nauki prawa doby Oświecenia w Polsce. Toruń: Państwowe Wydawnictwo Naukowe, 1962.

Salmonowicz, Stanisław. Księga pamiątkowa 400-lecia Toruńskiego Gimnazjum Akademickiego, vol. 4: Toruńskie Gimnazjum Akademickie w latach 1681-1817. Studium $z$ dziejów nauki i oświaty. Edited by Zbigniew Zdrójkowski. Poznań: Państwowe Wydawnictwo Naukowe, 1973.

Salmonowicz, Stanisław. "Le droit romain en Pologne à l'époque des Lumières." In Studi in onore di Edoardo Volterra, vol. 2, 351-370. Milano: Giuffrè, 1971.

Salmonowicz, Stanisław. "Les droits de l'homme dans la Constitution du 3. Mai 1791 et la tradition des libertés de la noblesse polonaise." In The Origin of Human Rights: The Constitution of 3 May 1791, the French Declaration of Rights, the Bill of Rights: Proceedings at the Seminar Held at the Nicolaus Copernicus University, May 3-5, 1991, edited by Janusz L. Justyński, 59-68. Toruń: Wydawnictwo Adam Marszałek, 1991.

Salmonowicz, Stanisław. "Les vicissitudes de la réforme pénale en Pologne du XVIIIe siècle." In Le politiche criminali nel XVIII secolo, edited by Luigi Berlinguer and Floriana Colao, 461-484. Milano: Giuffrè, 1990.

Salmonowicz, Stanisław. Ludwik Muzyczka 1900-1977. Polityk i żołnierz. Przyczynek do dziejów Armii Krajowej. Warszawa: Instytut Historii PAN, Warszawska Oficyna Wydawnicza „Gryf”, 1992.

Salmonowicz, Stanisław. Ludwik Muzyczka 'Benedykt' (1900-1977). Materiały historyczne do dziejów Komendy Głównej Armii Krajowej. Warszawa: Instytut Pamięci Narodowej, 2018.

Salmonowicz, Stanisław. Ludzie i dzieło Sejmu Czteroletniego. Toruń: Wojewódzka Biblioteka Publiczna i Książnica Miejska im. Mikołaja Kopernika, 1988.

Salmonowicz, Stanisław. "Maciej Nizolius (1568?-1608), rektor toruńskiego gymnasium academicum, wykładowca prawa rzymskiego." In Leges sapere. Studia i prace dedykowane Profesorowi Januszowi Sondlowi w pięćdziesiąta rocznice pracy naukowej, edited by Wacław Uruszczak, Paulina Święcicka and Andrzej Kremer, 485-497. Kraków: Wydawnictwo Uniwersytetu Jagiellońskiego, 2008.

Salmonowicz, Stanisław. "Michał Patkaniowski (1907-1972). Przyczynek do dziejów Wydziału Prawa i Administracji UJ.” In Stanisław Salmonowicz. W cieniu Klio $i$ Temidy. Studia $z$ historii prawa, 105-140. Toruń: Wydawnictwo Naukowe Uniwersytetu Mikołaja Kopernika, 2011.

Salmonowicz, Stanisław. "Między strachem a manipulacją. Inteligencja polska wobec stalinizmu." Prace Komisji Historii Nauki PAU 7 (2005): 81-104.

Salmonowicz, Stanisław. “Moja sprawa karna 1970/1971.” Dzieje Najnowsze 42/4 (2010): 115-139.

Salmonowicz, Stanisław. Myśl Oświecenia w Toruniu. Toruń: Toruńskie Towarzystwo Kultury, 1982.

Salmonowicz, Stanisław. "Narodziny nowożytnej myśli kodyfikacyjnej w Europie.” Czasopismo Prawno-Historyczne 29/1 (1977): 77-104. 
Salmonowicz, Stanisław. "Niemieckie ordynacje policyjne (XVI-XVIII wiek). Uwagi o sytuacji badawczej." Czasy Nowożytne 23 (2010): 151-177.

Salmonowicz, Stanisław. "O badaniach nad dziejami techniki legislacyjnej w Europie średniowiecza i w czasach nowożytnych." Miscellanea Historico-Iuridica 13/1 (2014): 237-252.

Salmonowicz, Stanisław. "O dziejach nauki prawa w Polsce. Problemy i perspektywy badawcze.” Czasopismo Prawno-Historyczne 50/1 (1998): 235-240.

Salmonowicz, Stanisław. "O dziejach Wydziału Prawa UJ w dobie II RP." Krakowskie Studia $z$ Historii Państwa i Prawa 10/2 (2017): 137-149.

Salmonowicz, Stanisław. “O niegodziwości procesów o czary." Czasopismo Prawno-Historyczne 46/1-2 (1994): 115-120.

Salmonowicz, Stanisław. “O procesach o czary w Polsce.” Czasy Nowożytne 21 (2008): 195-218.

Salmonowicz, Stanisław. "O procesach o czary w 'Prusach Brandenburskich'." Czasy Nowożytne 20 (2007): 299-311.

Salmonowicz, Stanisław. O rzemiośle recenzenta. Studia $z$ warsztatu historyka. Warszawa: Instytut Historii PAN, 1999.

Salmonowicz, Stanisław. Od XVI do XX wieku. Studia historyczne i historycznoprawne. Edited by Danuta Janicka. Toruń: Wydawnictwo Naukowe Uniwersytetu Mikołaja Kopernika, 2016.

Salmonowicz, Stanisław. "Patologie społeczne okresu okupacji hitlerowskiej." Czasy Nowożytne 3 (1997): 5-20.

Salmonowicz, Stanisław. "Penal Codes of the $16^{\text {th }}-19^{\text {th }}$ Centuries: A Discussion of Models." Comparative Law Review 2 (1991): 123-137.

Salmonowicz, Stanisław. Polnische Preussen oder Westpreussen. Ausgewählte Studien. Translated by Magdalena Darska-Łogin. Gdańsk: Instytut Kaszubski, Toruń: Pracownia Historii Pomorza i Krajów Bałtyckich Instytutu Historii PAN, 2018.

Salmonowicz, Stanisław. Polskie Państwo Podziemne. Z dziejów walki cywilnej 1939-45. Warszawa: Wydawnictwa Szkolne i Pedagogiczne, 1994.

Salmonowicz, Stanisław. Powstanie warszawskie. Próba uporządkowania problemów genezy i oceny ogólnej. Toruń: Torcon, 1990.

Salmonowicz, Stanisław. Prawo karne oświeconego absolutyzmu. Z dziejów kodyfikacji karnych przełomu XVIII/XIX w. Toruń: Towarzystwo Naukowe w Toruniu, Poznań: Państwowe Wydawnictwo Naukowe, 1966.

Salmonowicz, Stanisław. "Prawo prowincjonalne Prus Zachodnich i sprawa jego kodyfikacji (1772-1844)." Zapiski Historyczne 45/2 (1980): 25-59.

Salmonowicz, Stanisław. Preußen. Geschichte von Staat und Gesellschaft. Translated by Maria V. Stefanski. Herne: Stiftung Martin-Opitz-Bibliothek, 1995.

Salmonowicz, Stanisław. "Procesy o czary w Polsce. Próba rozważań modelowych." In Prawo wczoraj i dziś, edited by Grażyna Bałtruszajtys, 303-322. Warszawa: Liber, 2000.

Salmonowicz, Stanisław. "Profesorowie i studenci w dobie stalinizmu w Polsce (1944-1956)." In Polacy wobec PRL. Strategie przystosowawcze, edited by Grzegorz Miernik, 75-91. Kielce: Kieleckie Towarzystwo Naukowe, Akademia Świętokrzyska, 2003. 
Salmonowicz, Stanisław. Prusy. Dzieje państwa i społeczeństwa. Poznań: Wydawnictwo Poznańskie, 1987.

Salmonowicz, Stanisław. "Prusy Królewskie w Rzeczypospolitej polsko-litewskiej. Uwagi porównawcze." In Rzeczpospolita wielu narodów i jej tradycje. Materiały $z$ konferencji 'Trzysta lat od początku unii polsko-saskiej. Rzeczypospolita wielu narodów i jej tradycje', Kraków 15-17 IX 1997 r., edited by Andrzej K. Link-Lenczowski and Mariusz Markiewicz, 115-123. Kraków: Towarzystwo Wydawnicze „Historia Iagellonica”, 1999.

Salmonowicz, Stanisław. "Prusy Królewskie w strukturach Rzeczypospolitej (15691772).” In Rzeczpospolita w XVI-XVIII wieku. Państwo czy wspólnota?, edited by Bogusław Dybaś, Paweł Hanczewski and Tomasz Kempa, 159-167. Toruń: Wydawnictwo Naukowe Uniwersytetu Mikołaja Kopernika, 2007.

Salmonowicz, Stanisław. "Prusy Królewskie w ustroju Rzeczypospolitej szlacheckiej (1569-1772)." In Studia z dziejów Rzeczypospolitej szlacheckiej, edited by Krystyn Matwijowski and Zbigniew Wójcik, 45-57. Wrocław: Wydawnictwo Uniwersytetu Wrocławskiego, 1988.

Salmonowicz, Stanisław. "Rechtslehre und Rechtswissenschaft am Thorner Gymnasium Academicum im 17. Jahrhundert." In Europa in der Frühen Neuzeit. Festschrift für Günter Mühlpfordt, vol. 3, edited by Erich Donnert, 485-493. Köln, Weimar, Wien: Böhlau Verlag, 1997.

Salmonowicz, Stanisław. "Rewolty ludowe, rewolucje burżuazyjne, reformy odgórne. Uwagi o trudnościach klasyfikacji." Czasopismo Prawno-Historyczne 35/1 (1983): 249-260.

Salmonowicz, Stanisław. "Status prawny Polaka pod okupacja niemiecką (1939-1945). Uwagi o potrzebie badań.” Krakowskie Studia z Historii Państwa i Prawa 9/3 (2016): 345-360.

Salmonowicz, Stanisław. Studia z historii prawa (XVI-XX wiek). Bydgoszcz: Wydawnictwo Kujawsko-Pomorskiej Szkoły Wyższej, 2010.

Salmonowicz, Stanisław. Sylwetki spod gilotyny. Warszawa: Państwowe Wydawnictwo Naukowe, 1989.

Salmonowicz, Stanisław. Szkice toruńskie z XVII-XVIII wieku. Toruń: Towarzystwo Naukowe w Toruniu, 1992.

Salmonowicz, Stanisław. "Śmierć nie zawsze w majestacie prawa. Z dziejów kary śmierci w krajach niemieckich.” Czasopismo Prawno-Historyczne 49/1-2 (1997): $321-337$.

Salmonowicz, Stanisław. "The Legal Status of Poles under German Occupation (1939-1945): Some Remarks on the Need for Research.” Krakowskie Studia z Historii Państwa i Prawa (2017) special issue: 95-110.

Salmonowicz, Stanisław. Toruń w czasach baroku i oświecenia. Szkice z dziejów kultury Torunia XVII-XVIII wieku. Warszawa: Państwowe Wydawnictwo Naukowe, 1982.

Salmonowicz, Stanisław. "Tragiczna noc okupacji niemieckiej. O problematyce 'kolaboracji oddolnej' w Generalnym Gubernatorstwie." Studia Iuridica Toruniensia 11 (2003): 143-173.

Salmonowicz, Stanisław. "Vom Unfug der Hexenprozesse." Acta Poloniae Historica 74 (1996): 173-180. 
Salmonowicz, Stanisław. W cieniu Klio i Temidy. Studia z historii prawa. Toruń: Wydawnictwo Naukowe Uniwersytetu Mikołaja Kopernika, 2011.

Salmonowicz, Stanisław. W staropolskim Toruniu (XVI-XVIII w.). Studia i szkice. Toruń: TNOiK „Dom Organizatora”, 2005.

Salmonowicz, Stanisław. "Wandea. Anatomia ludowej kontrrewolucji." Kwartalnik Historyczny 74/4 (1967): 945-962.

Salmonowicz, Stanisław. "Wizerunek kodeksu. Constitutio Criminalis Carolina." Roczniki Nauk Prawnych 13/1 (2003): 53-66.

Salmonowicz, Stanisław. "Wkład polskiej nauki prawa do światowego dziedzictwa." In Wkład osiagnięć polskiej nauki i techniki do dziedzictwa światowego, edited by Irena Stasiewicz-Jasiukowa, 305-321. Warszawa, Kraków: Wyższa Szkoła Filozoficzno-Pedagogiczna „Ignatianum”, Wydawnictwo WAM, 2009.

Salmonowicz, Stanisław. "Wokół sporów o definicję i chronologię zjawiska Oświecenia." Czasy Nowożytne 25 (2012): 113-138.

Salmonowicz, Stanisław. "Z dziejów absolutyzmu oświeconego w Austrii." Czasopismo Prawno-Historyczne 38/1 (1986): 153-161.

Salmonowicz, Stanisław. "Z dziejów walki o tzw. restaurację autonomicznych aspiracji Prus Królewskich w XVIII wieku." Analecta Cracoviensia 7 (1975): 433-457.

Salmonowicz, Stanisław. "Z dziejów wschodniopruskich kodyfikacji prowincjonalnych (XVII-XIX w.). Przyczynek do losów prawa chełmińskiego w państwie brandenbursko-pruskim." In Studia Culmensia Historico-Juridica czyli Księga pamiątkowa 750-lecia prawa chetmińskiego, vol. 2, edited by Zbigniew Zdrójkowski, 271-326. Toruń: Uniwersytet Mikołaja Kopernika, 1988.

Salmonowicz, Stanisław. "Z problematyki procesów o czary. Uwagi na marginesie najnowszej literatury." Czasopismo Prawno-Historyczne 13/2 (1961): 209-221.

Salmonowicz, Stanisław. Z wieku Oświecenia. Studia z dziejów prawa i polityki XVIII wieku. Toruń: Wydawnictwo Uniwersytetu Mikołaja Kopernika, 2001.

Salmonowicz, Stanisław. 'Życie jak osioł ucieka.... Wspomnienia. Bydgoszcz, Gdańsk: Instytut Pamięci Narodowej, 2014.

Salmonowicz, Stanisław, Janusz Szwaja and Stanisław Waltoś. Pitaval krakowski. Warszawa: Wydawnictwo Prawnicze, 1962.

Salmonowicz, Stanisław, Marek Ney-Krwawicz and Grzegorz Górski. Polskie Państwo Podziemne. Warszawa: Światowy Związek Żołnierzy Armii Krajowej, Oficyna Wydawnicza RYTM, 1999.

Salmonowicz, Stanisław and Stanisław Grodziski. "Ustawa karna zachodniogalicyjska z roku 1796. Zarys dziejów i charakterystyka.” Czasopismo Prawno-Historyczne 17/2 (1965): 125-149.

Sieyès, Emmanuel J. Czym jest stan trzeci? Esej o przywilejach. Translated by Mikołaj Jarosz. Warszawa: Wydawnictwo Sejmowe, 2016.

Stobiecki, Rafał. Historiografia PRL. Zamiast podręcznika. Łódź: Wydawnictwo Uniwersytetu Łódzkiego, 2020.

Zasłużeni ludzie Pomorza Nadwiślańskiego XVII wieku. Szkice biograficzne. Wrocław: Zakład Narodowy im. Ossolińskich, 1982. 